\title{
Lobbying AND Agricultural TRAde Policy in the United States
}

\author{
KISHORE GAWANDE* \\ BUSH SCHOOL OF GOVERNMENT, TEXAS A\&M UNIVERSITY \\ BERNARD HOEKMAN \\ World Bank, Groupe D’Economie Mondiale, Sciences PolitiQues, AND CEPR
}

\begin{abstract}
This paper studies whether political campaign contributions influence agricultural protection in the United States in the manner suggested by the political economy model of Grossman and Helpman (1994). This is the first attempt to test this model using agricultural data. We test the model using a detailed cross-sectional data set of agricultural protection, subsidies, and PAC contributions in the late 1990s. The model is qualitatively affirmed by the data. We make a novel attempt to solve a puzzle about the model's quantitative implications, also found in recent studies. This solution makes the simple model consistent with the complicated decision-making process in real world government. The results imply the underpinnings of a political economy equilibrium that will be hard to dislodge.
\end{abstract}

World Bank Policy Research Working Paper 3819, January 2006

The Policy Research Working Paper Series disseminates the findings of work in progress to encourage the exchange of ideas about development issues. An objective of the series is to get the findings out quickly, even if the presentations are less than fully polished. The papers carry the names of the authors and should be cited accordingly. The findings, interpretations, and conclusions expressed in this paper are entirely those of the authors. They do not necessarily represent the view of the World Bank, its Executive Directors, or the countries they represent. Policy Research Working Papers are available online at http://econ.worldbank.org.

\footnotetext{
*Helen and Roy Ryu Professor of International Affairs, Bush School of Government. Texas A\&M University, College Station, TX 77843-4220. Email: kgawande@tamu.edu. Phone: (979) 458-8034.

We thank Marcelo Olarreaga for access to valuable data on agricultural protection and subsidies. The paper has benefited greatly from the insightful comments of two anonymous referees.
} 


\section{Introduction}

Total support to agriculture in the OECD has remained steady at some US\$300 billion per year. Two-thirds of this amount is generated by instruments that support domestic prices, especially border protection, and one-third by direct fiscal subsidies. The incidence of the former is mostly borne by domestic consumers, while the costs of the latter are incurred by taxpayers. Tariffs in agriculture are many times those applied to manufactures. The use of nontariff measures is as prolific in agriculture as it has become in manufacturing.

Understanding the political economy of agricultural support policies in OECD countries is important for those who foot the bill. Adoption of more efficient policy instruments to achieve agricultural objectives requires a good understanding of who is gaining from the status quo. It is also important in order to effectively negotiate in a multilateral forum, so that opposing sets of countries can identify policy packages that can mobilize domestic political support for reforms. de Gorter and Swinnen motivate the study of the political economy of agricultural policy as: "Understanding why governments do as they do allows one to analyze the policy formation process and alter incentive constraints through institutional reform in order to achieve desired policy outcomes". ${ }^{1}$ To this hopeful end, this paper employs a structural approach to understanding the political economy of U.S. agricultural protection.

The approach is very much based on the notion that governments trade off their own personal interests with the costs that their policies impose on society. Thus, lobbying by special interests is intrinsic to the theory. While previous empirical studies find associations between special interests and agricultural protection, they lack the discipline imposed by theory on their empirical models. A primary objective of this paper is to undertake a theoretically motivated empirical analysis of agricultural protection. We employ the Grossman-Helpman political economy model to investigate whether agricultural protection is a consequence of political campaign contributions. ${ }^{2}$ This model has come into prominence with the advent of empirical work

\footnotetext{
${ }^{1}$ de Gorter and Swinnen (2002, p. 1903).

${ }^{2}$ Grossman and Helpman (1994).
} 
endorsing its predictions, at least qualitatively. ${ }^{3}$ The model predicts protection to be a simple function of the existence of lobbying organization, the inverse of the import-to-output and export-to-output ratios and the import demand and export supply elasticities. The tightness of its theoretical predictions make the model amenable to testing using cross-sectional data. We apply the Grossman-Helpman model to the case of US agricultural trade policy, using precise measures of lobbying organization and agricultural protection and subsidies to a cross section of agricultural commodities from the late 1990s. To our knowledge this is the first study to use agriculture data to test the Grossman-Helpman model. It is also the first to seriously consider subsidies within the Grossman-Helpman framework.

We go beyond previous empirical studies of the Grossman-Helpman model as well. We would expect a government that is influenced by contributions to trade off consumer welfare loss for contribution dollars on an about equal basis. However, previous studies indicate that the US government is actually a welfare lover and places almost negligible weight on contributions. This paper suggests a novel resolution for that puzzle. We show that it is the consequence of taking a feature of the theory all too literally. Doing away with the "unitary" government assumption and introducing policy uncertainty, that is, making the model more real-worldly, rids the paradox.

The paper proceeds as follows. Section 2 briefly surveys the literature. It emphasizes the difference between the reduced form methods traditionally used in the agriculture protection literature and the structural method implemented in this paper. In Section 3 the GrossmanHelpman model is introduced and its main predictions stated and described. The data are described in Section 4. The data are new and theoretically appropriate for testing the model. In Section 5 the model's prediction is tested and the results analyzed. A puzzle posed by this and previous empirical work in this area is resolved. Section 6 concludes.

\footnotetext{
${ }^{3}$ Eicher and Osang 2002, Gawande and Bandyopadhyay (2000), Goldberg and Maggi 1999, Mitra, Thomakos, and Ulubasoglu 2002, and McCalman 2004. See survey by Gawande and Krishna (2004).
} 


\section{The first-generation literature}

A number of authors have advanced extensions of the pressure group model building on a combination of the Olson-Stigler-Downs model. ${ }^{4}$ Empirical evidence concerning the determinants of the structure of agricultural protection is plentiful. Two studies provide a flavor for the results. Olper estimates a reduced form econometric model of Common Agricultural Policy (CAP) transfers. ${ }^{5}$ His results indicate that protection is positively correlated with adverse market conditions (supporting the counter-cyclicality hypotheses of Bullock), inversely correlated with comparative disadvantage (supporting the Stolper-Samuelson effects that motivate losers to organize politically to oppose liberalization), and inversely correlated with high budget shares devoted to food consumption (perhaps indicating government's concern for welfare losses from protection). Honma applies the well known Anderson-Hayami framework to a panel of 14 industrial countries between 1955-1987 to find that protection is inversely correlated with high productivity (relative to industry) in agriculture and positively correlated with a decline in the terms of trade in agriculture. ${ }^{6}$

While this "first generation" of empirical studies conveys the message about the endogeneity of protection in agriculture, the empirical specifications they employ are ad hoc, with tenuous links to underlying theory. While they find strong associations of agricultural price distortions with some variables, the reduced form models cannot distinguish between competing theories. What theory are the results informing? Which theory should serve as the lens for best viewing the world of agricultural protection? This paper is motivated by the need in the literature to begin second-generation work that is more theory-based and less ad hoc than the studies that led the way. The Grossman-Helpman model has the potential to become the dominant theoretical paradigm in the international economics literature as it offers a consistent and rigorous framework that integrates a number of the economic and political variables that motivated the

\footnotetext{
${ }^{4}$ Olson (1965), Stigler (1971), Downs (1957). See also de Gorter and Tsur (1991). de Gorter and Swinnen (2002) provide the most up to date survey of this literature.

${ }^{5}$ Olper (1998).

${ }^{6}$ Honma (1993), Anderson and Hayami (1986). These findings also support Anderson's (1982) hypothesis that contraction of the agricultural sector reduces consumers' resistance to agricultural protection and, by causing greater concentration, encourages political lobbying by farmers.
} 
first generation political economy models (and rejects others). Since this model is inspired by the political system prevalent in the United States, it is particularly well suited to be applied to U.S. agricultural protection.

This paper thus departs in two important ways from previous empirical work. First, we employ a structural approach, where the empirical model is tightly linked with the theory. Second, rather than employing approximate measures of protection, we use ad valorem equivalents of protective instruments, just as the theory demands it. ${ }^{7}$ The structural model allows a symmetric treatment of subsidies as well as protection. This feature of the theory is attractive for a study of agriculture, a sector in which a variety of protection and subsidy instruments are used. We exploit this to test a complete version of the Grossman-Helpman model.

\section{The Grossman-Helpman Model}

The Grossman-Helpman general equilibrium theory of how trade policy responds to lobbying contributions delivers a precise prediction about the cross-sectional structure of tariffs and subsidies. ${ }^{8}$ In their model, money causes votes and is the source of electoral strength. A fact that supports this view is that lobbying contributions account for a significant share, up to $80 \%$, of the total campaign expenditures of the majority of congresspersons. ${ }^{9}$

A unitary government is assumed to maximize a weighted sum of welfare $(W)$ and lobbying contributions $(C)$ :

\footnotetext{
${ }^{7}$ Traditionally, protection is measured by the nominal protection coefficient (NPC) which measures the difference between world and domestic prices as a result of the protection support, or the effective protection coefficient (EPC) which measures the amount by which protection raises value added, or producer/ consumer subsidy equivalent (PSE, CSE) which measures the monetary benefit to producers/consumers as a percentage of production value in the absence of protection. We use ad valorem equivalents of tariffs and NTMs, which are more appropriate for the theory.

${ }^{8}$ Grossman and Helpman (1994)

9 Authors own observations from perusing a number of congressional profiles between 1980 and 2000 comprehensively summarized by Congressional Quarterly in their "Politics in America" volumes.
} 


$$
G=a W+C,
$$

where $a$ is the weight the government puts on a dollar of welfare relative to a dollar of contributions. ${ }^{10}$ Free trade would be the efficient outcome if the government maximized welfare alone. Here government trades off welfare loss imposed on consumers by its policies for campaign contributions by those who stand to gain from those policies. The parameter $a$ determines the terms of this tradeoff.

First, consider producers of good $i$ that compete with imports. An ad valorem import tariff $t_{i}$ on good $i$ raises its price $p_{i}$ above the world market price $p_{i}^{W}$. Revenues from the tariff are redistributed on a lump-sum basis to individuals in the economy. These individuals differ only in their ownership of sector-specific factors. Each individual owns capital that is specific to the production of one good. The supply of any sector-specific capital is limited, hence the rewards to specific capital used to produce good $i$ increase with $p_{i}$. This provides owners of sectorspecific capital in any import-competing sector an incentive to politically organize and lobby the government for a tariff. ${ }^{11}$

Now consider producers of good $i$ that export to the rest of the world. An ad valorem export subsidy $s_{i}$ on good $i$ raises its price $p_{i}$ above the world market price $p_{i}^{W}$. The costs of the subsidy are collected on a lump-sum basis from individuals in the economy. Symmetric to the import-

${ }^{10}$ While the political science literature has debated and gone beyond unitary government theories, formally complete models with more sophisticated forms of government are rare. The unitary government construct may be at the heart of why quantitative implications of empirical studies of the Grossman-Helpman model make the government out to be welfare maximizers even though this is inconsistent with the data. We return to this issue in the discussion of the empirical results, and offer a resolution that features congressional decision-making.

${ }^{11}$ Cross-commodity linkages are absent from the model, so that organized producers lobby only for protection to their good, not against protection on other goods. Consumers are the only group hurt by the tariffs. The relatively small input-output coefficients among the set of agricultural goods indicates that this assumption is well worth making for agricultural goods, and simplifies the model considerably. Cross-commodity linkages can be theoretically accommodated but introducing competition among lobbies makes the predictions less simple. Lopez (2001) studies cross-commodity linkages using a reduced form approach. 
competing case, owners of sector-specific capital in exporting sectors have an incentive to politically organize and lobby the government for a subsidy.

Suppose that sector $i$ is an import-competing sector (the analysis for an exporting sector is symmetric). The lobby representing import-competing producers of good $i$ presents government a menu that indicates the monetary contribution the lobby promises to make for each and every possible tariff $t_{i .}{ }^{12}$ The menu may obviously offer zero contributions for some values of the tariff (resp. subsidy). What considerations go into determining the menu? The lobby must recognize that the government maximizes (1), in particular that government is concerned about the collective welfare of consumers. Consider the extreme example of just one lobby (in order to abstract from lobbying competition) which exists, say, in sector 1, and whose membership is negligible relative to the population. Lobby 1 competes with imports and in order to induce the government to protect it, the lobby submits a menu of offers matching a money contribution to every possible tariff. This menu is its contribution schedule $\mathrm{C}_{1}\left(t_{1}\right)$. The government can choose protect this sector with a tariff that raises $p_{1}$ above the world price and collect the contribution associated with that tariff level (promised in the menu), or ignore the lobby and collect nothing from it. If the value of the political welfare function (1) with a zero tariff on good 1 equals $G_{0}$, then in order to obtain a more favorable policy, lobby 1 must ensure the government its status quo welfare of at least $G_{0}$. That is, it must compensate the government to the extent of the welfare loss from protecting sector $1 .^{13}$ From (1), it is evident that in order for government's welfare to remain unchanged, the contribution $C_{1}\left(t_{1}\right)$ for a tariff of $t_{1}$ must equal $-a \Delta W$, where $\Delta W$ is the change in the population's welfare due to the deadweight loss from the tariff.

We proceed by making the simplifying assumption that the politically organized population is a negligible fraction of the country's total population. The assumption is approximately satisfied

\footnotetext{
${ }^{12}$ Formally, the menu is the set of contributions $\left\{C_{i}\left(t_{i}^{j}\right), j=1, \ldots, \infty\right\}$ that maps each and every possible tariff for good $i$ into a dollar contribution.

${ }^{13}$ In this example, the single lobby gets to keep any and all surplus (the aggregate change in the welfare of each member net of contributions). When there is more than one lobby, due to the competition from other lobbies, they may be forced to collectively contribute beyond the welfare loss to the government. In that case, the government extracts part of that surplus (see Grossman and Helpman, 2004, Section 4).
} 
for the U.S. agriculture sector that we empirically consider in the paper. The corresponding predictions without this assumption are provided in accompanying footnotes. The assumption simplifies the main testable implication of the model in a manner that has both intuitive and empirical appeal. With the contribution schedules of the organized sectors in hand, the government sets equilibrium tariffs and subsidies that satisfy the following equations: ${ }^{14}$

$$
\begin{aligned}
& \frac{t_{i}}{1+t_{i}}=\left(\frac{1}{a}\right) \times\left(I_{i} \times \frac{z_{i}^{M}}{e_{i}^{M}}\right), \text { if } i \text { 's producers compete with imports, and } \\
& \frac{s_{i}}{1+s_{i}}=\left(\frac{1}{a}\right) \times\left(I_{i} \times \frac{z_{i}^{X}}{e_{i}^{X}}\right), \text { if } i \text { 's producers export. }
\end{aligned}
$$

In (2) $t_{i}$ is the ad valorem tariff on imports of good $i$ and $s_{i}$ is the ad valorem subsidy on good $i$ in political equilibrium. $I_{i}$ is an indicator variable that equals one if producers in sector $i$ are politically organized into a (import-competing or exporting) lobby. $a>0$ is the government preference parameter. $z_{i}^{M}=y_{i} / m_{i}$ is the equilibrium ratio of domestic output to imports and $e_{i}^{M}$ is the absolute elasticity of import demand. ${ }^{15} z_{i}^{X}=y_{i} / x_{i}$ is the equilibrium ratio of domestic output to exports and $e_{i}^{X}$ is the elasticity of export supply. If good $i$ is imported it is

${ }^{14}$ In order to formally derive (2) it is easiest to use the Goldberg-Maggi bargaining game approach. Consider an import-competing sector $i$. The equilibrium tariff in sector $i$ results from the maximization of the joint government-lobby (net) welfare function $G+W_{i}-C_{i}$ where $W_{i}-C_{i}$ is the welfare of lobby $i$ net of its contributions. When the proportion of organized specific factor owners (in all sectors) is negligible in the population, the welfare of lobby $i$ is simply the profits in sector $i$, or $\pi_{i}$. Profit in sector $i$ is a function of the sector $i$ tariff $t_{i}$. The joint government-lobby (in sector $i$ ) welfare is $a W+W_{i}$, where $W$ the country's welfare ( $W$ is the sum of economy-wide wage income, profits, tariff revenue, and consumer surplus -- the latter three being functions of tariffs). Applying the first order condition for a maximum to the joint net welfare, and noting that the lobbies in other sectors are too small to influence tariffs outside their own sectors, determines the optimal political-economic tariff in sector $i$ as the first equation in (2). A symmetric derivation for exporting sectors determines the optimal export subsidy according to the second equation in (2).

${ }^{15}$ Thus, the logic of Ramsey pricing applies. If the demand for a good is uniformly less elastic than that for another good, the optimal tax rate is higher for the first good due to the lower deadweight loss from taxing it rather than the second good. If the first good is totally inelastic there is no deadweight loss from taxing it, and the first best can be reached by taxing just this good. 
protected $\left(t_{i}>0\right)$ if it is politically represented by a lobby $\left(I_{i}=1\right)$ but not otherwise $\left(I_{i}=0\right)$; if $\operatorname{good} i$ is exported it is subsidized $\left(s_{i}>0\right)$ if it is politically represented by a lobby but not otherwise.

The right hand side of (2) indicates that protection to organized sectors is given according to their z/e ratios. Since the deadweight loss from protection (resp. subsidies) increases with the absolute import demand (export supply) elasticities, the tariff (subsidy) varies inversely with elasticities, all else equal. The numerator of $z$, that is, output, formalizes the notion of the stakes from protection and subsidies. Thus, contributions, and consequently protection/subsidies, vary directly with output. Finally, the lower the denominator of $z$ (imports or exports), the lower the social cost that a tariff or subsidy imposes on the population, making the government more amenable to distorting prices in those sectors. ${ }^{16}$

Equation (2) presents a precise and testable implication about the cross-sector pattern of protection and subsidies, and forms the basis for testing the Grossman-Helpman model. The tightness of the theoretical prediction makes it possible to measure the key political economy parameter $a$. The qualitative test of the model is that the coefficient on $\left(I_{i} \times Z_{i} / e_{i}\right)$ is positive.

${ }^{16}$ The corresponding expressions without making the assumption that the number of lobby members are a negligible fraction of the population are:

$$
\begin{aligned}
& \frac{t_{i}}{1+t_{i}}=\left(\frac{-\alpha}{a+\alpha}\right) \times \frac{z_{i}^{M}}{e_{i}^{M}}+\left(\frac{1}{a+\alpha}\right) \times\left(I_{i} \times \frac{z_{i}^{M}}{e_{i}^{M}}\right), \text { if } i \text { 's producers compete with imports, and } \\
& \frac{s_{i}}{1+s_{i}}=\left(\frac{-\alpha}{a+\alpha}\right) \times \frac{z_{i}^{X}}{e_{i}^{X}}+\left(\frac{1}{a+\alpha}\right) \times\left(I_{i} \times \frac{z_{i}^{X}}{e_{i}^{X}}\right), \text { if } i \text { 's producers export. }
\end{aligned}
$$

The new parameter $\alpha$ is the fraction of the population organized into lobbies, and measures the extent of opposition to protection. The first component on the right hand side of (2) indicates that negative protection to unorganized industries is given according to their $\mathrm{z} / \mathrm{e}$ ratios. This is because domestic consumers of that good (other than producers of the good) oppose protecting or subsidizing it since that raises the domestic price of the good. To the extent such consumers are politically organized they will lobby against protecting or subsidizing it. This component is less relevant for agricultural goods for the reason that if only a negligible fraction of consumers of agricultural goods were organized into lobbies $(\alpha=0)$, there would be no organized opposition to protecting any sector, only organized support for protecting a lobby's own sector. Since the proportion of income spent on food is small in advanced countries, there is little if any counter-lobbying by end consumers. Firms in food processing that use agricultural goods as intermediate inputs, who would normally oppose protection to agriculture, have chosen instead to lobby the government for protection to their sector. Mitra, Thomakos and Ulubasoglu (2002) pay careful attention to issues relating to the estimation of the parameters $a$ and $\alpha$, and discuss how one interacts with the other. 
Inverting the coefficient yields an estimate of $a$. The quantitative test of the model is whether these estimates of $a$ are reasonable.

Empirical testing of the Grossman-Helpman model using nontariff barrier (NTB) data from the 1980s in U.S. manufacturing has been undertaken in two studies, by Gawande and Bandyopadhyay, and Goldberg and Maggi. ${ }^{17}$ Since U.S tariff reductions were the subject of multilateral reductions in the Kennedy and Tokyo rounds, while the Grossman-Helpman model is one of unilateral protection, NTBs are more appropriate for testing the model. NTBs are measured as coverage ratios, that is, the percentage of imports covered by such barriers. Both studies qualitatively affirm the Grossman-Helpman model prediction. They find that protection increases with the inverse import-to-output ratio in politically organized industries (as measured by existence of PACs). ${ }^{18}$ However, they find the implied value of the government preference parameter $a$ to be surprisingly high - over 100 in the Goldberg-Maggi study and over 1000 in the Gawande-Bandyopadhyay study. If those estimates were taken literally, then the U.S. government would approximate the textbook ideal of welfare-maximizing entities!

\footnotetext{
${ }^{17}$ Gawande and Bandyopadhyay (2000) and Goldberg and Maggi (1999).

${ }^{18}$ Gardner's (1987) study is prescient about the Grossman-Helpman model's key features. In Gardner's model government maximizes the weighted sum of buyer's surplus (B) and producer's rents (R), B $+\theta R$. In turn, $\mathrm{B}$ and $\mathrm{R}$ are functions of farm output quantities. Efficient redistribution using production controls in this framework requires choosing quantities of farm products to maximize W. Unlike Grossman and Helpman, who adopt a formal model of the lobbying process and, as a result, are able to provide microfoundations for their objective function, Gardner does not provide micro-foundations for W. He employs Peltzman's (1976) "majority generating function" as the argument for using this type of objective function. He attributes the same forces that determine lobbying effectiveness as determining the value of the parameter $\theta$. Gardner measures these forces for seventeen farm commodity by the number of producers, their geographical dispersion, the stakes from redistribution (output per farm), and the stability of the industry (variability of production patterns). He also estimates (long-run) demand and supply elasticities for those commodities. Pooling data across the seventeen commodities over the period 191280 yields a sample of 1124 observations for Gardner's empirical analysis. The dependent variables are variants of the nominal protection coefficient. Gardner finds that the lower (greater) the (inverse) demand elasticity, the greater the level of intervention, that is, the higher the price relative to it's non-distorted price. This is a confirmation of the Grossman-Helpman intuition that it is most efficient to tax commodities with the lowest price elasticities of demand, and is the basis for Gardner's conclusion that interventions in U.S. agriculture have been efficient.
} 
The empirical work of Mitra, Thomakos and Ulubasoglu, and McCalman are notable for taking the theory to data outside the U.S. ${ }^{19}$ While they affirm the model's prediction, they too find an implausibly high implied value of the government preference parameter $a$. In both Turkey (Mitra et al.) and Australia (McCalman), governments attach more than 50 times as much weight on aggregate welfare as on contributions. This is grossly inconsistent with large deadweight losses that protection imposes on consumers as a number of U.S. case studies of protection demonstrate. ${ }^{20}$ Do agricultural protection data yield similar results?

Agricultural data allow us to add new features to the empirical testing of the Grossman-Helpman model, and thus significantly differentiate this study from the studies cited above and other forthcoming works. We are able to incorporate the use of subsidies into the model because they are pervasive in agriculture but rare in U.S. manufacturing. The pooling of both equations in (2) into one model is a unique feature of the paper. We also consider the two equations separately. We estimate three cross-sectional econometric models based on stochastic versions of equation (2). The first model is given by the two-equation set:

$$
\begin{aligned}
& \frac{t_{i}}{1+t_{i}}=\beta_{1}\left(I_{i} \times \frac{z_{i}^{M}}{e_{i}^{M}}\right)+\varepsilon_{i}, \quad \text { if } i \text { 's producers compete with imports, and } \\
& \frac{s_{i}}{1+s_{i}}=\beta_{1}\left(I_{i} \times \frac{z_{i}^{X}}{e_{i}^{X}}\right)+\varepsilon_{i}, \quad \text { if } i \text { 's producers export. }
\end{aligned}
$$

In (3) $\varepsilon_{i}$ is an identically independently distributed normal homoskedastic error term, which specifies the data generating process for the dependent variables. This model is estimated for the full sample of imported and exported goods. The model may be written with both equations stacked into a single equation with the terms redefined as:

\footnotetext{
${ }^{19}$ Mitra, Thomakos and Ulubasoglu (2002) and McCalman (2002).

${ }^{20}$ See e.g. Hufbauer, et al. (1986) and de Melo and Tarr (1990). Gawande and Krishna's (2004) survey draws attention to this puzzle.
} 


$$
\frac{g_{i}}{1+g_{i}}=\beta_{1}\left(I_{i} \times \frac{z_{i}}{e_{i}}\right)+\varepsilon_{i}
$$

where $g_{i}=t_{i}$ and $z_{i} / e_{i}=z_{i}^{M} / e_{i}^{M}$ if $i$ is an imported good, and $g_{i}=s_{i}$ and $z_{i} / e_{i}=z_{i}^{X} / e_{i}^{X}$ if $i$ is an exported good. Data on protection and subsidies from 1998 are used to estimate this model across a cross-section of agricultural goods. The parameter of interest $a$ is recovered as the inverse of the estimate of the coefficient $\beta_{1}$.

Concern about the endogeneity of the regressor compels using the appropriate methodology. Quite clearly, import penetration (inverse of $z^{M}$ ) is influenced by protection and the export-tooutput ratio (inverse of $z^{X}$ ) is influenced by subsidies. Further, which sectors are capable of organizing politically is also influenced in part by their expectation of the degree to which they will benefit from tariffs and subsidies. Thus, the regressor $I_{i} . Z_{i} / e_{i}$ is a nonlinear transformation (here product) of two endogenous variables, and is therefore itself endogenous. In order to estimate the coefficient $\beta_{1}$ consistently we construct exogenous variables capable of instrumenting the component endogenous variables, and then use the method of Kelejian to instrument the composite regressor. ${ }^{21}$ The Kelejian method simply requires us to use not only the instruments linearly, but their higher order terms (quadratic, cross-products) as well.

Constructing instruments for the agricultural data is a nontrivial task due to paucity of data on variables that are truly exogenous. Testing the exogeneity of instruments is thus necessary. Even if instruments pass the test of exogeneity, it is prudent to investigate whether the instruments are "weakly" related to the endogenous regressor. If so, then it seriously affects inferences that may be made from small samples. An important literature has grown around this subject in recent years in response to strong concerns about the endogeneity problem in natural experiments. $^{22}$ These studies and others indicate that the first-stage $F$-statistic may be used to assess whether a weak instrument problem exists. If a weak instrument problem exists, the popularly used two-stage least squares (2SLS) estimator can suffer a possibly intolerable level of

\footnotetext{
${ }^{21}$ Kelejian (1971).

${ }^{22}$ See e.g. Stock and Staiger (1997) and Stock and Yogo (2005).
} 
bias. On the other hand, the limited information likelihood estimator (LIML) is a better-quality estimator and is more robust to the weak instrument problem. We report both the 2SLS and LIML results.

In addition to model (4) we also estimate two models for separate samples of imported goods and exported goods. Protection is modeled in the imported goods sample as

$$
\frac{t_{i}}{1+t_{i}}=\beta_{2}\left(I_{i} \times \frac{z_{i}^{M}}{e_{i}^{M}}\right)+\varepsilon_{i},
$$

and subsidies are modeled in the exported goods sample as

$$
\frac{s_{i}}{1+s_{i}}=\beta_{3}\left(I_{i} \times \frac{z_{i}^{X}}{e_{i}^{X}}\right)+\varepsilon_{i} .
$$

Whereas in model (4) it is assumed that government's policy preferences are constant regardless of whether their decision is about protection or about subsidies, (5) and (6) allow flexibility in this regard. Before turning to the task of testing the model, we discuss the data.

\section{Data}

\section{Protection}

The data on protection and subsidies we use are not only comprehensive in the range of instruments they cover, but are measured in a manner that fit the theoretical requirement of the model. ${ }^{23}$ They have been constructed as part of a World Bank project on trade restrictiveness. We use three measures of protection and two measures of subsidies produced by those studies. The first measure of protection is the ad valorem equivalent (AVE) of core nontariff measures

\footnotetext{
${ }^{23}$ We are grateful to Marcelo Olarreaga for access to this and other data that were constructed as part of the World Bank's project on trade restrictiveness.
} 
(Core NTMs) for each HS six-digit tariff line item estimated by Kee, Nicita and Olarreaga. ${ }^{24}$ AVEs of core $\mathrm{NTMs}^{25}$ (price and quantity control measures, technical regulations, as well as monopolistic measures, such as single channel for imports) are computed by Kee et al. using Leamer's comparative advantage approach. ${ }^{26}$

The second is an all-encompassing measure of protection, Overall Protection, which is the sum of all three possible sources of protection: tariffs, NTMs and domestic subsidies in agriculture. ${ }^{27}$ Since they are measured as ad valorem equivalents, they are summed to yield an overall measure of protection.

The third is a complete tariff measure, All Tariff, which combines ad valorem tariffs with (ad valorem equivalents of) specific tariffs. ${ }^{28}$ Both measures have been historically prevalent in agriculture, and since agriculture was untouched by the multilateral rounds of negotiations

\footnotetext{
${ }^{24}$ Kee, Nicita and Olarreaga (2004b).

${ }^{25}$ Core NTMs include quantitative restrictions, price control measures, monopolistic measures and technical regulations corresponding to codes $6000,8000,7000$ and 8100 in the UNCTAD TRAINS database, which is the source of the NTB indicators.

${ }^{26}$ Leamer's (1990) method is as follows. First, imports are predicted using factor endowments. Then the impact of NTBs on imports is measured as deviations of imports, in the presence of NTMs, from these predicted values. Finally, this quantity impact of NTMs on imports is converted into a price equivalent (or AVE) by using the import demand elasticities estimated in Kee, Nicita and Olarreaga (2004).

${ }^{27}$ The source of the dollar value of agriculture domestic subsidies is $\mathrm{Ng}$ and Olarreaga (2004), obtained from WTO members' notifications during 1999. The method of computing the AVE of domestic support is to treat them as NTMs and apply the same method as for Core NTMs. Production subsidies vary widely in their uses and aims. They include direct payments to producers (such as deficiency payments), input subsidies (on irrigation water, for example), policies that distort market prices (market price supports), and interest subsidies on commodity loan programs. Also included in these measures are the "boxed" policies demarcated in the Uruguay round. These include direct payments and price support benefits that directly influence production ("amber box"), payments tied to limits on production ("blue box" policies), research, domestic food aid, environmental programs, and certain crop insurance and income safety net programs ("green box" policies).

${ }^{28}$ The main source of the ad valorem tariff data is the WTO Integrated Data Base (IDB). Specific (dollar/unit) tariffs can be converted to their ad valorem equivalents by dividing the specific tariff by the unit value of the imported product. The International Trade Commission (ITC) provides the data to accomplish this at the tariff line level.
} 
(before the Doha round), they are imposed largely unilaterally. Agricultural tariff data are therefore appropriate for testing the Grossman-Helpman model.

The subsidy measures are taken from Hoekman, Ng and Olarreaga. ${ }^{29}$ Unlike the protection measures, the closest we can get to an ad valorem equivalent is the ratio of the dollar value of the subsidy to the dollar value of exports. Two subsidy measures are available, export subsidies as a proportion of exports, XS, and total subsidies (including production and export subsidies) as a proportion of exports, $\mathrm{TS}^{30}{ }^{30}$ All protection and subsidy data are for the year 1999.

\section{Trade and Output}

The USDA's Production, Supply and Distribution database PSD Online (at http://www.fas.usda.gov/psd/complete files/default.asp) is the source for trade and production data. The data are kept at a commodity level that map neatly into the harmonized system (HS) of trade data-keeping at the 4-digit or 5-digit level. Since imports and production are both measured in physical units in the database, they yield precise measures of the inverse import-to-output $\left(\mathrm{z}^{\mathrm{M}}\right)$ and inverse export-to-output ratios $\left(z^{\mathrm{X}}\right)$.

We use the following criteria to categorize commodities as pure import or pure export goods: if for any commodity $z^{\mathrm{M}}>30$ (imports small relative to output) and $z^{\mathrm{X}}<30$ then it is categorized as a pure export good; if for a commodity $z^{\mathrm{X}}>30$ (exports small relative to output) and $z^{\mathrm{M}}<30$ then it is categorized as a pure import good. In the data, in sectors where one ratio is greater than the cutoff of 30 , the other is considerably less than 30 , so that the cutoff clearly separates the exported commodities from import-competing ones. ${ }^{31}$

\footnotetext{
${ }^{29}$ Hoekman, Ng and Olarreaga (2004).

${ }^{30}$ The range of included production subsidy measures can influence imports as well as exports -production subsidies can curtail imports (by increasing domestic production) or promote exports (by lowering production costs). For goods with one-way trade (goods that are purely exported or imported), it is clear what the subsidies achieve. For goods with two-way trade, we solve the problem by replicating them in the sample -- once for imports, and once for exports. Protection data are used only with the imports sub-sample, while subsidy data are used only with the exports sub-sample.

${ }^{31}$ This applies to commodities with zero imports (so that $z^{\mathrm{M}}$ is infinite), and zero exports $\left(z^{\mathrm{X}}=\infty\right)$.
} 
If both $z^{\mathrm{X}}<30$ and $z^{\mathrm{M}}<30$ then the sector is categorized as a two-way trade sector. In the sample, they are replicated, once as an import good for which $z^{\mathrm{M}}$ is the relevant variable, and once as an export good for which $z^{X}$ is relevant. Thus, in the sample used to estimate (4), there are 94 observations, 41 for imports and 53 for exports.

Another study by Kee, Nicita and Olarreaga estimates U.S. import demand elasticities at the tariff line level using the GDP function approach. ${ }^{32}$ Since the import demand elasticity variable consists of estimated values, we treat it as a variable measured with error, but with known measurement error variances (equal to the square of their standard error of estimate). A Fuller correction is applied to the variable before it is used as the denominator in the $z / e$ variable. ${ }^{33}$ Corresponding estimates of export supply elasticities are unfortunately unavailable. Since most agricultural goods are relatively undifferentiated it is reasonable to assume that their export supplies are elastic. We therefore set the export supply elasticity equal to 2 for all goods.

\section{Lobbying}

Agricultural PAC spending data for the three congressional election cycles between 1993-1998 were downloaded from the Federal Election Commission (FEC) website. ${ }^{34}$ The main use to which the PAC spending data are put is to measure lobbying organization. ${ }^{35}$ Whether a good $\mathrm{i}$ has political representation $\left(\mathrm{I}_{\mathrm{i}}=1\right)$ or not $\left(\mathrm{I}_{\mathrm{i}}=0\right)$ is determined on the basis of PAC spending summed over this period. Goods are ordered by PAC spending and sets of I are defined, each set corresponding to a percentile cutoff value. Models (4)-(6) are estimated using all these

\footnotetext{
${ }^{32}$ Kee, Nicita and Olarreaga (2004a). See e.g. Kohli (1991) for the GDP function method. In this method imports are treated as inputs into domestic production, given exogenous world prices, productivity and endowments.

${ }^{33}$ Fuller (1986). The idea behind this correction is to limit the influence of estimates that are large and also have large standard errors. Without the correction, these large estimates would grossly overstate the true elasticity. The correction mutes their effect.

34 www.fec.gov.

${ }^{35}$ Mapping PACs into SIC-based agriculture-related sectors was done via a concordance constructed by Beaulieu and Magee (2002). In most cases many PACs mapped into one SIC code, so SIC level contributions are simply the aggregate of the mapped PACs. For one-to-many maps, political contributions from each PAC were fractionally assigned equally to each SIC code into which the PAC mapped. To check for consistency we compared our data with the data on the opensecrets.com website. For the few sectors in which opensecrets.com reports such information our data closely matched theirs.
} 
alternative I-sets in order to gauge the robustness of the results to measures of political organization.

It is instructive to examine some features of PAC spending data, and assess whether they are in line with the Grossman-Helpman idea of money buying policy (as different from money buying mere access to policymakers). ${ }^{36}$ Farm PACs contributed between $\$ 5.5$ million and $\$ 7$ million during each of the five election cycles. Among farm products, the most politically active were sugar PACs, dairy PACs and ranch PACs. Together these three PACS accounted for about $75 \%$ of total farm PAC contributions. ${ }^{37}$ Over 200 PACs were politically active during this period. Cotton, dairy and wheat had the highest degree of PAC concentration, and represented by the equivalent of three or four equal sized PACs. Ranch, sugar, and fruits and vegetables were represented by the equivalent of eight to ten equal-sized PACs. ${ }^{38}$

PAC money is clearly influential in agriculture. A study of the 1985 and 1990 voting during sugar legislations by Brooks, Cameron and Carter finds that in the House and Senate both votes were responsive to sugar PAC contributions. ${ }^{39}$ Further, the value of sugar production in their constituency also determined how congresspersons voted. Sugar lobbies also targeted candidates that were likely to advance pro-sugar policies.

Two-thirds of agricultural PAC money went to House candidates and one-third to Senate candidates. Figure 1 indicates the top 20 recipients in the House of agriculture PAC contributions during the 1993-94 election cycle. ${ }^{40}$ During this cycle, 13 of the top 20 House recipients of

\footnotetext{
${ }^{36}$ Gawande (2006) details the structure of lobbying in agriculture over the 1990-2000 period in the United States.

${ }^{37}$ Food manufacturing PACs, forestry and nursery PACs, agriculture service PACs and agriculture distribution PACs contributed more than did farm PACs.

${ }^{38}$ Based on Herfindahl indices computed by the authors.

${ }^{39}$ Brooks, Cameron and Carter (1998). Lopez (2001) also finds that PAC contributions influenced agricultural policies in other sectors.

${ }^{40}$ The PAC data are in three relational data files: candidate information files $(\mathrm{CN}), \mathrm{PAC}$ committee information files (CM), and files containing transactions between PACs and candidates (PAS). For each election cycle, aggregate contributions by each PAC to every candidate were computed from the PAS
} 
agricultural PAC money were members of the influential House Agricultural committee. They included the committee chair (de la Garza) and three subcommittee chairs (Stenholm, Rose, Volkmer). Figure 2 bears out much the same story for the 1997-98 election cycle. The pattern of giving in these figures clearly indicates that agricultural PACs targeted politicians with influence over agriculture policy. The amounts are not inconsequential. For example, in the 1993-94 cycle, agricultural PACs delivered between 8\% (Fazio) and 60\% (de la Garza) of the total PAC money received by the top twenty "Ag PAC" recipients. ${ }^{41}$

\section{Instrumental Variables}

Since the regressor is composed of the endogenous variables $I$ and $z$ we construct two exogenous variables from the agriculture census of 1997 that identify each of the endogenous variables. The first instrument, termed PaymentConcentration, is a measure of geographic concentration and pressure. It is constructed using data on total government payments available for each state. Total government payment to a state is then distributed across the top four commodities produced in that state. ${ }^{42}$ This approximates how much each commodity gets by virtue of its being a visible top four commodity in the state. Summing across the states gives us variable PaymentConcentration which measures government payments to each visible commodity. The second instrumental variable termed Farmland is simply the acres of land in farms for each crop. The first variable is constructed in order to identify political organization and the second to identify the output-to-imports and output-to-exports ratio z. Since the regressor in model (4) is a composite of the two, for identification we use linear, quadratic, and cross-product of these two variables as our set of instruments.

files, and then merged with the relevant cycle's CN files. Agriculture committee and sub-committee assignments for each Congress were obtained from Congressional Quarterly (1996-1999).

${ }^{41}$ Top 20 list-makers who were not on the Agricultural committee represented districts with influential agricultural constituents (CA, OK, VA, MI). For example, Fazio's district (CA, district 3) was among the 30 leading districts by market value of agricultural products (1997 Census of Agriculture).

${ }^{42}$ These include payments for acreage reductions, commodity credit loans, payments for meeting environmental targets satchel wetlands, etc. 


\section{Empirical Analysis}

\section{Results}

The first set of results we discuss are estimates of model (4) using the sample of 94 observations in which both import-competing and exported goods are stacked. Each row in Table 2 contains estimates of $\beta_{1}$ from seven specifications of model (4). Each specification uses a different definition of political organization, $I_{i}$. Their purpose is two-fold. First, contributions do not necessarily imply that a particular commodity is politically represented in the trade arena, the relevant policy domain for the Grossman-Helpman model. Agricultural producers have historically benefited from a basket of instruments such as acreage controls in addition to trade protection and subsidies. ${ }^{43}$ To the extent that PAC contributions are directed not only at traderelated instruments, a single contributions-based definition may mismeasure $I_{i}$. Second, a range of measures of political organization makes the results consistent with a broad set of beliefs, and also conveys the robustness of the results to different measures of political organization.

Each of the six rows in Table 2 defines the dependent variable differently. The first two rows use the $\{$ Core NTM, Subsidy\} combination for the dependent variable, that is, for import-competing goods protection is measured as Core NTMs while for exported goods subsidies are measured as export subsidies (row 1) or total subsidies (row 2). The next two rows use the \{Overall Protection, Subsidy combination, and the final two rows use the \{Tariff, Subsidy\} combination. A diverse range of instruments is thus represented in Table 2, allowing for a more inclusive test of the Grossman-Helpman model than previous tests that have used data only on imports.

The 42 models in Table 2 are estimated using Kelejian's two-stage least squares (2SLS) method (see Section 3), using as instruments the variables PaymentConcentration, Farmland, their squares and cross-products. In the first model in Table 2, 90\% of the sample is organized. The variable $I_{i}$ equals 1 if total PAC spending over the 1993-98 period for sector $i$ is ranked above the bottom tenth percentile of the sample. $t$-values are reported next to the estimates of $\beta_{1}$. Shaded $t$-values denote statistical significance for 1-tailed test. The signs and statistical significance on the estimates affirm the Grossman-Helpman prediction across all models, even those with few (though influential) politically organized sectors. The positive and statistically significant

\footnotetext{
${ }^{43}$ Goldstein, 1989 provides an illuminating account of the evolution of agricultural institutions.
} 
estimates of $\beta_{1}$ demonstrate that political organization increases agricultural protection to import competing sectors and subsidies to exporting sectors according to their $z / e$ ratio. For commodities whose producers are politically organized, the greater the stakes from protection (high output) and the lower the deadweight loss from protection (low imports, low $e$ ), the greater is the difference between domestic and world prices.

A change in $z / e$ in an organized industry changes the level of protection/subsidy by $\beta_{1}>0$. For example, the middle two rows of Table 2 indicate that an increase in the output-to-import or output-to-export ratio by 100 would increase the dependent variable in (4) by anywhere between $18 \%$ and $24 \%{ }^{44}$ This translates into an increase in the price received by the domestic producer by approximately $19 \%$ to $26 \%$ at the sample mean (of 0.082 ). ${ }^{45}$ Since it is highly likely that between $10 \%$ and $80 \%$ of the commodities (more precisely, observations in the sample) are actually organized those estimates capture reality.

Quantitatively, the results echo a puzzling finding from previous examinations of the GrossmanHelpman model that used manufacturing data. Inverting the coefficient estimate yields estimates of the government preference parameter $a$. These implied estimates are skewed towards welfare. The last two columns of Table 2 indicate that, across the models, the implied estimates of $a$ lies between 47.6 and 62.5 when the dependent variable is the Core NTM, Export subsidy/Total subsidy\} combination, between 41.7 and 55.6 with the \{Overall Protection, Export subsidy/Total subsidy combination, and between 83.3 and 100 with the \{Tariff, Export subsidy/Total subsidy combination. They show that government places far greater weight on a dollar of welfare, at least 40 times as much, as on a dollar contributed politically.

The first robustness test we undertake is with respect to the validity of the five instruments used in the first stage. The set of instruments pass the Sargan test of overidentification, that is, the

\footnotetext{
${ }^{44}$ In the cross section, due to wide disparities in the $\mathrm{z} / \mathrm{e}$ ratios, differences of that magnitude are not uncommon.

${ }^{45}$ A one percent change in the dependent variable in (4), $g /(1+g)$, translates into a $(1+g)$ percent raise in the ad valorem tariff or subsidy, $g$. At the sample mean of $g=0.082$ (see Table 1) we obtain these estimates.
} 
instruments prove to be exogenous and uncorrelated with the errors in the structural equation. But that in itself is not sufficient to guarantee reliable inferences in small samples if instruments are "weak". Intuitively, when instruments are only weakly related to the endogenous regressor, then $t$-tests based on conventional asymptotic approximations can be quite inaccurate. Stock and Yogo show that, with five instruments, the first-stage $F$-statistic must be greater than 6.40 in order for the bias of the 2SLS estimator relative to the (large sample) bias of the OLS estimator to be lower than $20 \%{ }^{46}$ Table $\mathrm{A} 1$ in the appendix shows that except for the models with $I 10$ and I80, the first stage $F$-statistics are greater than 6.40, and the 2SLS estimates are significant improvements over their OLS counterparts. Even so, it is worth investigating whether the more robust limited information likelihood estimators (LIML) change the inferences significantly. Table 3 presents the LIML estimates of the parameter $\beta_{1}$. As the last two columns indicate, the estimates do not significantly lower the estimates of the preference parameter $a$. They continue to show that the U.S. government places at least 40 times as much weight on a dollar of welfare as on a dollar of lobbying money.

A second set of robustness tests is based upon new political organization variables constructed by predicting PAC spending from a linear regression with the output-to-import or output-toexport ratio $\mathrm{z}$ as the regressor. This method yields better measures of trade-related lobbying than using the raw lobbying data. Table 4 presents results using these measures. The variable $I$ is now based on percentile cutoffs using the predicted value of PAC spending. The results prove robust to these new variables. The last two columns of Table 4 indicate somewhat larger implied estimates of $a$ when the dependent variable is the \{Core NTM, Export subsidy/Total subsidy\} or \{Overall Protection, Export subsidy/Total subsidy\}, and a somewhat smaller estimate with the \{Tariff, Export subsidy/Total subsidy\} combination. They show that government places at least 55.6 times (and as much as 83.3) as much weight on a dollar of welfare as on a dollar of contributions.

Does splitting the sample separately into import-competing and exporting goods alter the magnitudes of the $a$ estimates? This is the third set of robustness tests we undertake. Table 5 presents LIML estimates from the imports samples, where the dependent variables are measures

\footnotetext{
${ }^{46}$ Stock and Yogo (2005).
} 
of protection. The first stage F-statistics (see Table A2) lie between 4 and 5 for the imports sample, so that LIML proves to be the more robust estimator for this sample. The last two columns indicate that the preference parameter $a$ lies between 20.8 (Overall protection model) and 62.5 (All tariff model) across the three measures and the variety of $I$ measures - a relatively smaller range of estimates than with the full sample, but not significantly so.

Table 6 presents LIML estimates from the exports sample, where the dependent variables are the two subsidy measures. The first stage $F$-statistics (see Table A3) range from a low of 0.54 (model with I80) to a high of 5.27 (model with I60). The LIML estimator is therefore robust to the weak instrument problem for only models with intermediate measures of political organization. Therefore the lower limit of the $a$ estimates (which come from the model with I80) are quite unreliable. It would be safest to infer that $a$ exceeds 100 (and is less than 250) from the subsidy data. The results are therefore quite robust to differential rates of tradeoff between lobbying contributions and welfare that may characterize U.S. government preferences across policy instruments.

The main implication from the estimates of the preference parameter $a$ in Tables 2-6 is that the observed values of $z / e$ and their interactions with $I$ can only lead to the observed levels of NTB protection and subsidies if government puts great weight on welfare. That is, the U.S. government is approximately a welfare maximizer. But welfare maximization would lead to free trade, and trade in agriculture is by no means free! The deadweight losses from protection are considerable. Table 7 compiled from Hufbauer, Elliott, and Schott, indicates the extent of those losses from protection in U.S. agricultural products. ${ }^{47}$ They estimate the annual deadweight losses from protection due to sugar quotas during 1977-84 to be $\$ 540 \mathrm{mn}$, due to Section 22 protection of dairy products in 1983 to be $\$ 1.6$ bn., due to peanut quotas in 1983 to be $\$ 14 \mathrm{mn}$., due to voluntary export restraints of meat in 1983 to be $\$ 280 \mathrm{mn}$., and due to a policy to extend the fish conservation zone further out to sea to be $\$ 185 \mathrm{mn}$. On the subsidy side, Friedman estimates the deadweight losses from grain crop subsidies in 2002 to be between $\$ 2$ to $\$ 6$ billion

\footnotetext{
${ }^{47}$ Hufbauer, Elliott, and Schott (1986).
} 
per annum! $!^{48}$ The distortion in agricultural prices is substantial. To conclude that the large values of $a$ inferred from estimates of the Grossman-Helpman model require us to reject the role of politics in agricultural trade policy would be simplistic at best and a misrepresentation of the results at worst.

How is one to resolve this paradoxical finding about $a$ ? We start by exploring the idea that the large estimates of $a$ are a consequence of the model's assumption that contributions are far larger in magnitude than they actually are. As described in Section 3, in order to induce government to implement a policy, the change in contributions from any lobby due to a small change in policy must, at the margin, compensate the government an amount equal to $a$ times the loss in consumer welfare plus (in the case of a single lobby, and more if there is lobbying competition; see fn 6). ${ }^{49}$ But if deadweight losses are as large as the estimates in Table A1 (and those in Friedman) indicate, then according to the lobbying side of the Grossman-Helpman model the estimates of $a$ imply that we should observe lobbying spending in the billions of dollars! We thus term this puzzle the "case of the missing contributions".

\section{Reconciling the results: Lobbying under policy uncertainty}

In order to resolve the puzzle, we amend the theory to make it capable of generating the real world lobbying and protection data. A contribution of this paper is to bring the model closer to legislative reality. The Grossman-Helpman model presumes government to be a singular entity with the power to supply protection with certainty. In reality the legislative process leading to protection is uncertain. First, contributions are made ex ante to the award of protection or subsidy. They are not, as in the Grossman-Helpman model, made upon delivery of protection or subsidy. Second, lobbies make contributions to a number of political agents who, neither individually nor collectively, can guarantee a specific outcome like the unitary government of Grossman-Helpman can. The legislative studies literature has rejected the "straw man" unitary

\footnotetext{
${ }^{48}$ Friedman (2003) estimates are based on the following calculation: In 1995, total receipts for the grain crops were in the $\$ 40$ to $\$ 50$ billion range. Approximately 41.9 percent of these receipts come from direct or indirect government support, implying total transfers in the $\$ 17$ to $\$ 21$ billion range. The deadweight losses various studies have cited for different commodity programs are in the range of 10 to 30 percent of transfer payments, which is $\$ 1.7$ to $\$ 6.1$ billion for the grains.

${ }^{49}$ Mathematically this is immediate from differentiating (1) with respect to the vector of prices $\boldsymbol{p}$.
} 
government hypothesis. A voluminous literature in this area seeks to understand the complexities of the legislative process. Not only can a potential policy be stillborn as it fails in committee, in the chambers, or is vetoed by the executive, but even if it makes it through, its shape may be indelibly and unpredictably altered as it encounters gatekeepers, opportunists ("log-rollers"), and legislators with the power and influence to form deal-breaking coalitions at various stages of its journey. Legislative uncertainty is in fact the norm for trade policy owing to its essentially redistributive nature that creates gainers and losers. For example, the 1989 Trade Omnibus bill was characterized by logrolls, mark-ups, and an executive veto before a much milder and less protectionist form of legislation was passed by Congress.

Thus, protection is for sale, but uncertainly, since lobbying contributions are made in advance of knowing the outcome. Specifically, unlike the GH model in which the government is promised a contribution $C_{t_{i}^{j}}$ by lobby $i$ for every possible tariff $t_{i}^{j}, j=1, \ldots, \infty$, and collects from lobby $i$ its promised contribution $C_{t_{i}^{*}}$ after delivering a particular policy $t_{i}^{*},{ }^{50}$ in reality each lobby must make a contribution knowing only that a policy $t_{i}^{j}$ can be delivered only uncertainly. For simplicity, let us characterize this legislative uncertainty using a probability parameter $\gamma$. Lobbies know that each and every policy vector (of tariffs) is supplied with probability $\gamma$, and denied with probability $(1-\gamma)$. Then (assuming risk-neutrality on the part of lobbies), lobby $i$ will set its contribution $C_{t_{i}^{j}}$ for the particular tariff $t_{i}^{j}$ at the level at which it maximizes the lobby's expected welfare. The optimal political economic tariffs and subsidies are then given by the following equations: ${ }^{51}$

\footnotetext{
${ }^{50}$ A specific policy here is a vector of tariffs and subsidies across all goods, where, under the assumption that a negligible proportion of the population is organized, each lobby is concerned about only that element of the vector pertaining to its own sector, that is, its own tariff/subsidy.

${ }^{51}$ In order to understand this more formally, compare the maximization of the joint government-lobby $i$ net welfare function under certainty about policy versus uncertainty. The former is given in $\mathrm{fn} .7$ as $G+W_{i}-C_{i}$ where $W_{i}-C_{i}$ is the welfare of lobby $i$ net of its contributions. Under uncertainty, where the government can deliver a tariff $t_{i}$ with probability $\gamma$, the joint net welfare function becomes $G+\gamma W_{i}-C_{i}$, since ex ante to the policy lobby $i$ can only maximize expected welfare. Applying the first order condition for a maximum to the joint net welfare under uncertainty now determines the optimal politicaleconomic tariff in sector $i$ as the first equation in (3), and the optimal export subsidy as to the second equation in (3).
} 


$$
\begin{aligned}
& \frac{t_{i}}{1+t_{i}}=\left(\frac{\gamma}{a}\right) \times\left(I_{i} \times \frac{z_{i}^{M}}{e_{i}^{M}}\right), \text { if } i \text { 's producers compete with imports, and } \\
& \frac{s_{i}}{1+s_{i}}=\left(\frac{\gamma}{a}\right) \times\left(I_{i} \times \frac{z_{i}^{X}}{e_{i}^{X}}\right), \text { if } i \text { 's producers export. }
\end{aligned}
$$

The parameter $\gamma$ sharply differentiates the equilibrium in (7) from that in equation (2). Under uncertainty, the political economy parameter $a$ is retrieved as $\gamma / \beta_{1}$ from the econometric model (3). Thus, if $\gamma=0.10$, the estimate of parameter $a$ drops to between 4 and 6 , or one-tenth of the estimate under certainty (using LIML estimates in the first two rows of Table 3 ). Bringing uncertainty about government's ability to deliver policy into the Grossman-Helpman model thus brings many results into line with reasonable prior beliefs based on facts about (low) contributions and (large) deadweight losses.

An intuitive approach to understand the mechanism that is altered by introducing policy uncertainty is to consider what happens to lobbying contributions. Consider the instructive case of a single lobby which exists, say, in sector 1. As described in Section 3 (subsequent to equation (1)), under certainty the lobby presents the government with a menu of contributions in which it promises to pay the government $a$ times the deadweight loss (DWL) for every possible tariff. This clearly overstates actual contributions in the real world. Under uncertainty, the lobby pays the government (ex ante to the policy) an amount equal to $a$ times $\gamma$ times the deadweight loss (DWL) from the expected tariff. For example, if contributors viewed the probability of protection to be $10 \%$, then contributions in the same model would equal a time expected deadweight loss, or $a \times 0.1 \times \mathrm{DWL}$. The government receives far less in contributions than the deadweight losses its policies impose, since the contributions come ex ante to the policy. The "case of the missing lobbying" thus stands resolved. ${ }^{52}$

\footnotetext{
${ }^{52}$ We can approach PAC spending formally. Consider the expression that approximates DWL in a sector (see e.g. Vousden, 1990):

$\mathrm{DWL} / y \approx 0.5 \times[t /(1+t)]^{2} \times e / z$,

where $y$ is output (see fn. 27). Substituting for $t /(1+t)$ from (2) yields

$\mathrm{DWL} / y \approx 0.5 \times\left[\beta_{1} \times \mathrm{z} / e\right]^{2} \times e / z$

$=0.5 \times 1 / a^{2} \times \mathrm{z} / e$, or
} 
Further, the actual level of protection to sector 1 is lower because contributions are lower. If contributions are thought of as being determined within the unitary government framework of Grossman and Helpman, when in reality they are determined ex ante to a policy that a divided government can only deliver with uncertainty, then the level of protection will be (erroneously) predicted to be greater than it is in reality. The result is that the unitary government model leads to the conclusion that the low tariffs are due to a welfare-loving government, when in reality it is a self-interested government that delivers tariffs in response to (lower) contributions under uncertainty.

On the supply side, why should a mulit-layered government agree to provide redistributive policies to a handful of winners at a low price? To this question, we provide an intuitive answer but await more formal explanations from future research. In the real world, in order to maximize the impact of their limited budgets (determined by the lobby upon their assessment of the policy uncertainty parameter $\gamma$ ) agricultural lobbies strategically target a handful of politicians, such as ranking members of the House and Senate agriculture committees. Congresspersons on the agricultural committee are more than willing to bear their share of the deadweight loss from distortionary agricultural policy. It is clear from Figures 1 and 2 that representatives of agricultural constituencies vie for membership on agricultural committees so that not only are they able to influence policy to suit their constituencies but are also lobbied in the process. Formal extensions of the Grossman-Helpman theory in this direction should recognize the paramount importance of committees in legislative decisions. ${ }^{53}$

$a \times \mathrm{DWL} / y \approx 0.5 \times 1 / a \times \mathrm{z} / e$.

In the single-lobby case described above, the numerator on the left hand side equals PAC spending in the Grossman-Helpman model, or $\mathrm{PAC} / y \approx 0.5 \times 1 / a \times z / e$.

Thus PAC spending by the industry's lobby as a fraction of industry output is predicted by the GrossmanHelpman model to be proportional to $z / e$, the factor of proportionality being (approximately) 0.5/a. With legislative uncertainty, the mapping from DWL into $\mathrm{z} / \mathrm{e}$ is modified as protection (an therefore) DWL becomes probabilistic in the eyes of the lobby. Thus, if $\mathrm{E}(\mathrm{DWL})=\gamma \times \mathrm{DWL}$, then and thus $a \times \mathrm{E}(\mathrm{DWL}) / y \approx 0.5 \times \gamma / a \times(\mathrm{z} / e)$,

$\mathrm{PAC} / y \approx 0.5 \times \gamma / a \times(\mathrm{z} / e)$.

Under uncertainty the model predicts that PAC spending as a fraction of output is proportional to $(z / e)$ the factor of proportionality being (approximately) $0.5 \times \gamma / a$.

${ }^{53}$ See e.g. Fenno (1973), Grier and Munger (1991), and Weingast and Marshall (1988). 
Once the issue leaves the committee for the floor, why should other congresspersons that bear the deadweight loss, but are not compensated by lobbies, care to vote for the distortionary policy? Distributional models of legislative organization recognize that legislators are a heterogeneous group and care differentially about different issues. ${ }^{54}$ Mutual gains makes it almost necessary to trade votes across issues. In this view, agriculture committee members are supported in exchange for their reciprocal support on issues on which the agriculture committee members bear their portion of deadweight loss without being compensated. Proof of vote trading in the U.S. congress and its quantitative importance is demonstrated by Stratmann. Stratmann finds that vote trading among farm interests is widespread, and that such logrolling coalitions exhibited a strong degree of stability. ${ }^{55}$ His analysis of logrolling during voting on the 1985 Farm Bill shows strong evidence that legislators traded votes. ${ }^{56}$ Moreover, legislators with intense preferences, such as members of the House agriculture committee, were the most likely to trade votes.

It is appropriate at this stage to consider whether competing views about lobbying might not be more relevant than the Grossman-Helpman view of lobbying as exchange. An alternate view is one where lobbying spending provides access to politicians. This opens the door for lobbies to provide politicians with information that benefits them and simultaneously implies policies that benefit the lobbyist. ${ }^{57}$ Hansen discusses milestones in agricultural policymaking during the twentieth century that he posits were due to informational lobbying. ${ }^{58}$ Might not informational lobbying be a worthy alternative to the quid-pro-quo lobbying of the Grossman-Helpman model?

\footnotetext{
${ }^{54}$ Martin and Simmons (1998).

${ }^{55}$ Stratmann (1995).

${ }^{56}$ Stratmann (1992).

${ }^{57}$ This theory was originally developed in Bauer, Pool and Dexter (1963) and Millbraith (1960).

${ }^{58}$ Hansen (1991) finds that in the 1950s and 60s farm policy makers dropped the American Farm Bureau Federation (AFBF) from its dominant position in agricultural politics. AFBF had been agriculture's leviathan for a generation. In the $60 \mathrm{~s}$ and the $70 \mathrm{~s}$ commodity organizations replaced the position previously occupied by the AFBF. Also, in the 60s and the 70s farm policy makers paid less and less attention to the advice of farm lobbies. In the $70 \mathrm{~s}$ and $80 \mathrm{~s}$, this was reversed, and they scarcely paid attention to the advice of consumer lobby. In sum, during those 40 years, congress reallocated access
} 
Evidence on the effectiveness of informational lobbying in agriculture is, at best, feeble. Wright finds only very weak evidence of informational lobbying of the House Agriculture committee, the most influential policymaking committee in agriculture. ${ }^{59}$ He attributes the weak finding to the fact that the Agriculture committee deals with a narrow and well defined set of issues on a periodic basis (as different from Ways and Means which attacks a range of diverse issues, often on an ad hoc basis). Both, leaders and rank and file members of the Agriculture committee, have ample opportunity to regularly interact with lobbies. The preferences of agricultural lobbies have been fairly constant over time, and so those preferences are well known to Agriculture committee members (in contrast to the Ways and Means Committee whose members encounter a wide range of lobbyists, many on an issue-by-issue basis, so that informational lobbying can be influential on the margin). Hence, informational lobbying of Agriculture committee members is not influential on the margin in the formation of coalitions. This view of Agriculture committee members possessing a strong continuing link with PACs whose preferences have been stable over time is endorsed in Parker and Parker. ${ }^{60}$ Agriculture is distinguished among committees for the stability of their coalitions as issues move from committee to the floor. Parker and Parker take this to imply that the influence of special interests on forming preferences of committee members on these committees is strong. In contrast, members of other committees often change their votes on the floor indicating that their preferences on committee were weak to begin with.

Therefore, we do not see a role for informational lobbying in agriculture, at least over the short duration of a decade. Our experiment is different from Hansen's, who considers a longer period in history during which there were points in time when Congress sought new information from lobbies. At those threshold points, informational lobbying may have led to marked shifts in how Congress began to view agricultural policy. On a continuing basis over the 1991-2000 period we

within the farm lobby, congress restricted access for the farm lobby but congress denied access to the consumer lobby. Hansen's theory of these changes in access is developed around (i) competitive advantage in a lobby's ability to deliver better information to politicians than their rival groups, and (ii) recurrence of issues around which a lobby makes its case to the politicians. Hence, politicians grant access to lobbies on the basis of their informational advantage over other lobbies, and also the permanence of the issues and positions conveyed by the lobbies.

${ }^{59}$ Wright (1991).

${ }^{60}$ Parker and Parker (1998). 
see little role for new information. Our view is thus that agricultural PACs contributions are more in the spirit of exchange or payments in political markets for protection, as Grossman and Helpman posit. With the "paradox of the high $a$ " resolved, the amended and extended Grossman-Helpman model presents an emerging new paradigm in the literature on the political economy of trade policy.

\section{Conclusion}

The theoretical lens of the Grossman-Helpman model is used in this paper to investigate the political economy of US agricultural protection and subsidies. Since the theory delivers clear empirical predictions about the structure of protection, empirical estimation of the determinants of protection and subsidies may be tightly linked to theory. The model thus encourages structural econometric estimation of the political economic determinants of protection and subsidies. This is in contrast to the ad hoc specifications in previous empirical, and, to be sure, not any less important, exploratory empirical work in this area. This is the first attempt at applying this model to study agricultural protection. Estimates from the model strongly affirm the qualitative implications of the Grossman-Helpman model. They clearly establish that interest-group money bends agricultural policy in the U.S.

Quantitatively, accepting the theory literally leads to the inferences that the U.S. government is a welfare maximizer. This is inconsistent with the large estimates of deadweight losses from distortionary policy in agriculture, and the small amount of money contributions that are able to "buy" that policy. We show that the puzzle is resolved by extending the model to allow uncertainty about the ability of politicians to deliver policy combined with the fact that contributions are made ex ante to the policy. It makes common sense that lobbies, which must determine how much to contribute under uncertainty about the "product" they wish to purchase, contribute much less than in a world where there is no uncertainty. ${ }^{61}$

The results of the empirical estimation clearly reveal the government-business political nexus that underlies the equilibrium with agricultural protection. Making agricultural liberalizations the

\footnotetext{
${ }^{61}$ Perhaps it is this uncertainty that forces them to try to gain access to policymakers to use forms of persuasion that are less costly than quid pro quo money payments.
} 
focus of the Doha round has caused the negotiations to stumble. If this is a "crisis of multilateralism" ${ }^{62}$ is the mechanism described in the paper so prevalent across the world that it lies at the source of the crisis? Are more stable cooperative outcomes more possible on a bilateral basis $?^{63}$ Our results expose a powerful source of international fissures that have challenged current multilateral negotiations.

Our resolution of the missing lobbying paradox also raises questions. We close on the note that these may also be answered in future research. What are realistic values of the uncertainty parameter $\gamma$ ? Should this parameter be modeled as being different for different sectors? Can structural models of policy uncertainty due to, for example, the existence of veto players ${ }^{64}$ be incorporated to generate realistic hypotheses of not only the structure of protection and subsidies but also about to how such uncertainty conditions lobbying behavior?

\footnotetext{
${ }^{62}$ Martin (1992).

${ }^{63}$ Yarbrough and Yarbrough (1992; Paarlberg (1997).

${ }^{64}$ Tsebelis (2002); Cox and McCubbins (2001).
} 


\section{References}

Anderson, Kym. 1992. International Dimensions of the Political Economy of Distortionary Price and Trade Policies. In Open Economies: Structural Adjustment and Agriculture, edited by Ian Goldin and L. Alan Winters, 290-310. Cambridge: Cambridge University Press.

Anderson, Kym. 2004. Subsidies and Trade Barriers, paper prepared for the Copenhagen Consensus project, World Bank, mimeo.

Anderson, Kym and Yujiro Hayami. 1986. The Political Economy of Agricultural Protection. Sydney: Allen and Unwin.

Bauer, Raymond, Ithiel de Sola Pool, and Lewis Dexter. 1963. American Business and Public Policy. New York: Atherton.

Beaulieu, Eugene, and Chris Magee. 2004. Four Simple Tests of Campaign Contributions and Trade Policy Preferences. Economics \& Politics 16 (2): 163 - 187

Brooks, Jonathan C., A. Colin Cameron, and Colin A. Carter. 1998. Political Action Committee Contributions and U.S. Congressional Voting on Sugar Legislation. American Journal of Agricultural Economics 80: 441-454.

Congressional Quarterly. 1994. Politics in America: 1994, the $103^{\text {rd }}$ Congress. Washington, DC: CQ Press.

Congressional Quarterly. 1995. Politics in America: 1996, the $104^{\text {th }}$ Congress. Washington, DC: CQ Press.

Congressional Quarterly. 1997. Politics in America: 1998, the $105^{\text {th }}$ Congress. Washington, DC: CQ Press.

Congressional Quarterly. 1999. Politics in America: 2000, the $106^{\text {th }}$ Congress. Washington, DC: CQ Press.

Cox, Gary W. and Mathew D. McCubbins. 2001. The Institutional Determinants of Economic Policy Outcomes. In Presidents, Parliaments, and Policy, edited by S. Haggard and M. D. McCubbins. Cambridge: Cambridge University Press.

de Gorter, H. and Y. Tsur. 1991. Explaining Price Policy Bias in Agriculture. American Journal of Agricultural Economics 73: 1244-1254.

de Gorter, H, and Johan F. M. Swinnen. 2002. Political Economy of Agricultural Policies. In Handbook of Agricultural Economics, edited by Bruce L. Gardner and Gordon C. Rausser. New York: Elsevier.

de Melo, Jaime and David Tarr. 1990. Welfare Costs of U.S. Quotas in Textiles, Steel and Autos. Review of Economics and Statistics :489-497.

Eicher, Theo, and Thomas Osang. 2002. Protection for Sale: An Empirical Investigation: Comment. American Economic Review 92: 1702-1710.

Fenno, Richard E. 1973. Congressmen in Committees. Boston: Little, Brown.

Friedman, Lee, S., 2003. Wither, or Whither, Agricultural Crop Subsidies? Unpublished manuscript. Keynote luncheon address American Agricultural Economics Association, Montreal, Canada.

Fuller, Wayne. 1986. Measurement Error Models. New York: Wiley.

Gardner, Bruce L. 1987. Causes of U.S. Farm Commodity Programs. Journal of Political Economy 97: 290-310.

Gawande, Kishore and Usree Bandyopadhyay. 2000. Is Protection for Sale? A Test of the Grossman-Helpman Theory of Endogenous Protection. Review of Economics and Statistics 89:139-152. 
Gawande, Kishore and Pravin Krishna. 2003. The Political Economy of Trade Policy: Empirical Approaches. In Handbook of International Trade, edited by James Harrigan and E. Kwan Choi. Oxford and Malden, MA: Blackwell.

Gawande, Kishore. 2006. The Structure of Lobbying and Protection in U.S. Agriculture. Forthcoming in Economic Development and Multilateral Trade Cooperation, edited by Bernard Hoekman and Simon Evenett. New York: Macmillan/Palgrave.

Goldberg, Pinelopi and Giovanni Maggi. 1999. Protection for Sale: An Empirical Investigation. American Economic Review 89: 1135-1155.

Goldstein, Judith. 1989. The impact of ideas on trade policy: The origins of U.S. agricultural and manufacturing policies. International Organization 43: 31-71.

Grier, Kevin B. and M. C. Munger. 1991. Committee Assignments, Constituent Preferences, and Campaign Contributions. Economic Inquiry 24-43.

Grossman, Gene and Elhanan Helpman. 1994. Protection for Sale. American Economic Review 84: 833-850.

Grossman, Gene and Elhanan Helpman. 2002. Interest Groups and Trade Policy. Princeton, NJ: Princeton University Press.

Hansen, John M. 1991. Gaining Access: Congress and the Farm Lobby, 1919-81. Chicago: University of Chicago Press.

Hiscox, Michael. 1999. The Magic Bullet? The RTAA, Institutional Reform and Trade Liberalization, International Organization 53:4, 669-98.

Hoekman, Bernard and Michel Kostecki. 1996. The Political Economy of the World Trading System: From GATT to WTO. Oxford: Oxford University Press.

Hoekman, Bernard, Francis Ng and Marcelo Olarreaga. 2004. Agricultural tariffs or subsidies: Which are more important for developing countries? World Bank Economic Review 18 (2), 175-204.

Honma, Masayoshi. 1993. Japan's Agricultural Policy and Protection Growth. In Trade and Protectionism, edited by T. Ito and Anne O. Krueger. Chicago: University of Chicago Press, 95-114.

Hufbauer, Gary C., Diane T. Berliner and Kimberly A. Elliott. (1986). :Trade Protection in the United States: 31 Case Studies. Washington, DC:Institute of International Economics.

Kee, Hiau Looi, Alessandro Nicita and Marcelo Olarreaga. 2004a. Import demand elasticities and trade distortions, Centre for Economic Policy Research, Working Paper \#4669, London, UK.

Kee, Hiau Looi, Alessandro Nicita and Marcelo Olarreaga. 2004b. Ad-Valorem Equivalents of Non-Tariff Barriers, mimeo, The World Bank, Washington DC.

Kelejian, Harry H. 1971. Two Stage Least Squares and Econometric Systems Linear in Parameters But Non-Linear in the Endogenous Variables. Journal of the American Statistical Association. 66: 373-374.

Kohli, Ulrich. 1991. Technology, duality and foreign trade: the GNP function approach to modeling imports and exports. Ann Arbor: The University of Michigan Press.

Leamer, Edward. 1990. Latin America as a target of trade barriers erected by the major developed countries in 1983, Journal of Development Economics 32, 337-368.

Lopez, Rigoberto. 2001. Campaign Contributions and Agricultural Subsidies, Economics and Politics 13:3, 257-79.

Martin, Lisa L., and Beth A. Simmons. 1998. Theories and Empirical Studies of International Institutions. International Organization 52: 729-757 
Martin, Lisa L. 1992. Interests, Power, and Multilateralism. International Organization 46: 765792.

McCalman, Philip. 2004. Protection for Sale and Trade Liberalization: An Empirical Investigation. Review of International Economics 12(1), 81-94.

Milbraith, Lester W. 1960. The Washington Lobbyists. Chicago: Rand-McNally.

Mitra, Devashish, Dimitrios D. Thomakos, and Mehmet A. Ulubasoglu. 2002. Protection for Sale in a Developing Country: Democracy Versus Dictatorship. Review of Economics and Statistics 84: 497-508.

Olper, Alessandro. 1998. Political Economy Determinants of Agricultural Protection Levels in EU Member States: An Empirical Investigation. European Review of Agricultural Economics 25: 463-87.

Olson, Mancur 1965. The Logic of Collective Action. Cambridge, MA: Harvard University Press.

Opensecrets, 2002. http://www.opensecrets.org

Paarlberg, Robert. 1997. Agricultural Policy Reform and the Uruguay Round: Synergistic Linkage in a Two-Level Game. International Organization 51: 413-444.

Parker, Glenn R. and Suzanne L. Parker. 1998. The Economic Organization of Legislatures and How it Affects Congressional Voting. Public Choice 95: 117-129.

Peltzman, Sam. 1976. Toward a More General Theory of Regulation. Journal of Law and Economics 19:211-240.

Schattschneider, E. E. 1935. Politics, Pressures, and the Tariff. New York, NY: Arno Press.

Staiger, Douglas and James H. Stock. 1997. Instrumental Variables Regression with Weak Instruments. Econometrica 65: 557-586.

Stigler, George J. 1971. The Theory of Economic Regulation. Bell Journal of Economics and Management Science 2: 3-21.

Stock, James H. and Motohiro Yogo. 2005. Testing for Weak Instruments in Linear IV Regression. In Identification and Inference in Econometric Models: Essays in Honor of Thomas J. Rothenberg, edited by D. W. K. Andrews and J. H. Stock. Cambridge: Cambridge University Press.

Stratmann, Thomas. 1995. Logrolling in the U.S. Congress. Economic Inquiry 33: 441-56.

Stratmann, Thomas. 1992. The Effects of Logrolling on Congressional Voting. American Economic Review 82: 1162-76.

Tsebelis, George. 2002. Veto Players: How Political Institutions Work. Princeton, NJ: Princeton University Press.

Vousden, Neil. 1990. The Economics of Trade Protection. Cambridge, UK: Cambridge University Press.

Weingast, B. R. and W. J. Marshall. 1988. The Industrial Organization of Congress; or Why Legislatures, Like Firms, are Not Organized as Markets. Journal of Political Economy 132-163.

Wright, John. 1990. Contributions, Lobbying, and Committee Voting in the U.S. House of Representatives. American Political Science Review 84: 417-438.

Yarbrough, Beth and Robert Yarbrough. 1992. Cooperation and Governance in International Trade. Princeton, NJ: Princeton University Press.

U.S. Department of Agriculture, Economic Research Service, 2002: http://www.ers.usda.gov UNCTAD. 2000. TRAINS Database. 
Figure 1: Top 20 HOUSE Recipients of AG PAC money: 1993.94 Election Cycle

D KY $[A G: E C R D, F A H, G F C] B A R L O W$ D MO [AG:DON,FAH,GFC,Chair L] VOLKMER R WI [AG:DON,ECRD,L] GUNDERSON V A BLILEY D VA PAYNE D CA [AG:FAH,L,SCNR,GFC] CONDIT D NC LANCASTER $R$ CA $[A G: E C R D, L, S C N R] P O M B O$ $R$ IA [AG:ECRD,FAH,GFC] NUSSLE R M O [AG:DON,FAH,GFC,SCNR] EM ERSON D CA [AG:DON,FAH,L,GFC] DOOLEY

D TX [AG:DON,ECRD,FAH,GFC] SARPALIUS $R$ KS [AG:] ROBERTS D IL DURBIN D CA LEHMAN D NC [AG:DON, FAH, L, Chair SCNR, GFC] ROSE D DC FAZIO D TX [AG:Chair DON, FAH, L, SCNR, GFC] STENHOLM D WA FOLEY D TX [AG:Chair] DELA GARZA

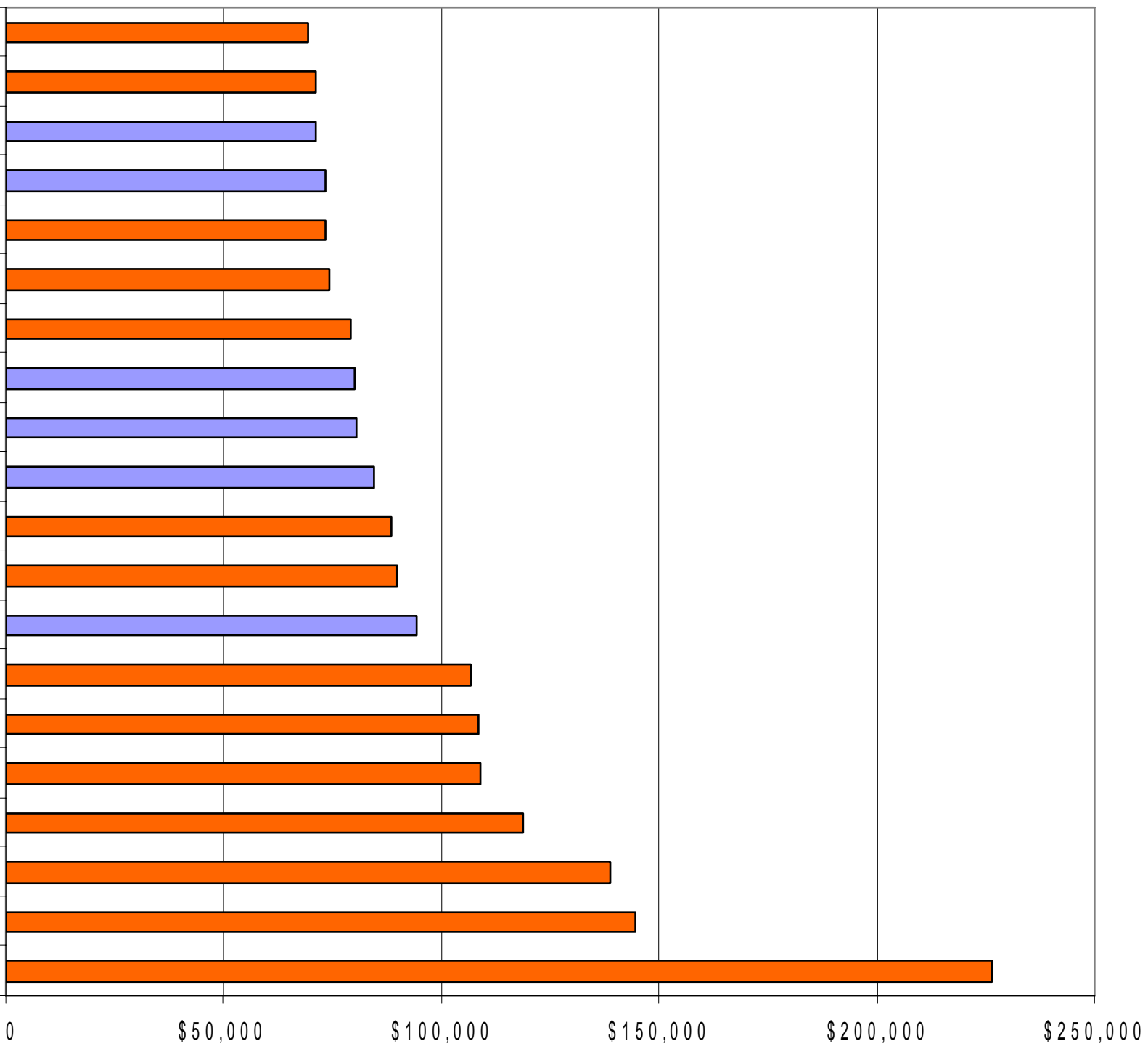


Figure 2: Top 20 HOUSE Recipients of AG PAC money: 1997.98 Election Cycle

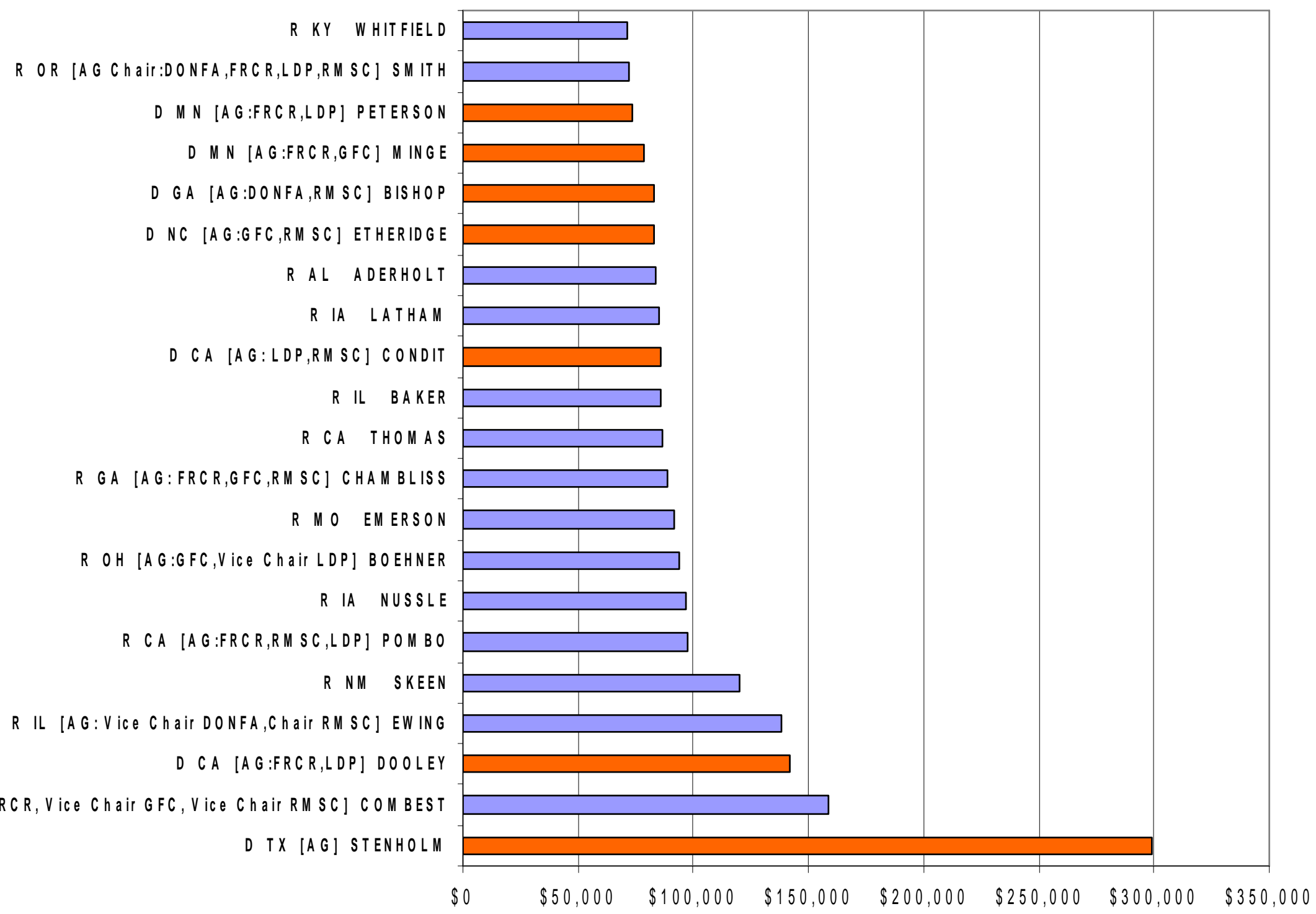


Table 1: Descriptive statistics. Three samples: (1) Imported Goods, (2) Exported Goods, (3) M and X goods

\begin{tabular}{|c|c|c|c|c|}
\hline & Short Description & Description & mean & sd \\
\hline \multirow{13}{*}{ 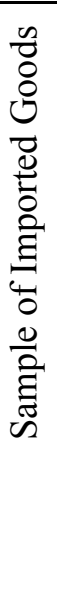 } & Core NTM & ad valorem equivalent of Core nontariff measures (NTM) & 0.137 & 0.180 \\
\hline & Overall Protection & valorem equivalent of All NTMs & 0.176 & 0.179 \\
\hline & All Tariff & valorem tariff + ad valorem equivalent of specific tariff & 0.127 & 0.218 \\
\hline & $z^{\mathrm{M}} / e^{\mathrm{M}}$ & oroduction/imports)/|import demand elasticity| & 5.208 & 6.241 \\
\hline & $z^{\mathrm{M}} / e^{\mathrm{M}} \times I 10$ & (see def of $I n$ in the notes below) & 4.564 & 6.381 \\
\hline & $z^{\mathrm{M}} / e^{\mathrm{M}} \times I 25$ & & 4.537 & 6.400 \\
\hline & $\mathrm{z}^{\mathrm{M}} / e^{\mathrm{M}} \times I 33$ & & 4.537 & 6.400 \\
\hline & $\mathrm{z}^{\mathrm{M}} / e^{\mathrm{M}} \times \mathrm{I} 40$ & & 4.268 & 6.447 \\
\hline & $\mathrm{z}^{\mathrm{M}} / e^{\mathrm{M}} \times \mathrm{I} 50$ & & 4.072 & 6.511 \\
\hline & $z^{\mathrm{M}} / e^{\mathrm{M}} \times I 60$ & & 3.827 & 6.552 \\
\hline & $z^{\mathrm{M}} / e^{\mathrm{M}} \times I 80$ & & 2.999 & 6.430 \\
\hline & PaymentConcentration & Geographic concentration measure based on govt. payments ( $\$ \mathrm{mn}$.) & 282 & 712 \\
\hline & Farmland & Farm & 0.109 & 0.120 \\
\hline \multirow{12}{*}{ 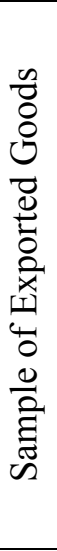 } & $\mathrm{XS}$ & exports & 0.010 & 0.057 \\
\hline & TS & $\mathrm{XS}+(1$ & 0.012 & 0.061 \\
\hline & $z^{\mathrm{X}} / e^{\mathrm{X}}$ & (production/exports)/export supply elasticity & 3.559 & 3.716 \\
\hline & $\mathrm{z}^{\mathrm{X}} / e^{\mathrm{X}} \times I 10$ & $\mathrm{z} / \mathrm{e} \times \mathrm{I} 10$ & 3.331 & 3.774 \\
\hline & $z^{\mathrm{X}} / e^{\mathrm{X}} \times 125$ & z/e x I 25 & 2.929 & 3.853 \\
\hline & $z^{X} / e^{X} \times I 33$ & $\mathrm{z} / \mathrm{e} \times \mathrm{I} 33$ & 2.929 & 3.853 \\
\hline & $z^{\mathrm{X}} / e^{\mathrm{X}} \times I 40$ & $\mathrm{z} / \mathrm{e}$ : & 2.158 & 2.830 \\
\hline & $z^{\mathrm{X}} / e^{\mathrm{X}} \times I 50$ & $\mathrm{z} / \mathrm{e} \mathrm{x}$ & 1.791 & 2.541 \\
\hline & $z^{\mathrm{X}} / e^{\mathrm{X}} \times \mathrm{I} 60$ & $\mathrm{z} / \mathrm{e} \times \mathrm{I} 60$ & 1.395 & 2.052 \\
\hline & $\mathrm{Z}^{\mathrm{X}} / e^{\mathrm{X}} \times I 80$ & $\mathrm{z} / \mathrm{e} \times \mathrm{I} 80$ & 0.786 & 1.669 \\
\hline & PaymentConce & Geographic concentration measure based on govt. paym & 306 & 622 \\
\hline & Farmland & Farm & 0.107 & 0.120 \\
\hline \multirow{18}{*}{ 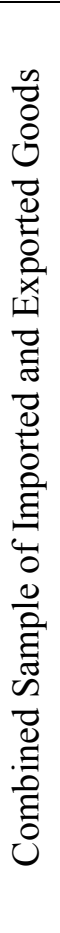 } & $\{$ Core, $\mathrm{XS}\}$ & Dependent variable measued as Core NTM if & 0.066 & 0.140 \\
\hline & & observation is $\mathrm{M}$ and $\underline{\mathrm{XS}}$ if observation is $\mathrm{X}$ & & \\
\hline & $\{$ Core, $\mathrm{TS}\}$ & $\{\underline{\text { Core NTM}}, \underline{\text { Total Subsidy }}\}$ & 0.066 & 0.141 \\
\hline & $\{$ Overall Protection, $\mathrm{XS}\}$ & $\{\underline{\text { All NTM + Tariff, }} \underline{\text { E }}$ & 0.082 & 0.150 \\
\hline & $\{$ Overall Protection, TS $\}$ & $\{\underline{\text { All NTM + Tariff, }} \underline{\text { Total Subsidy }}\}$ & 0.083 & 0.150 \\
\hline & $\{$ All Tariff, XS $\}$ & 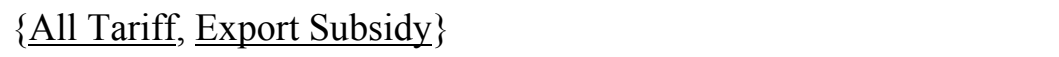 & 0.061 & 0.160 \\
\hline & $\{$ All Tariff, TS $\}$ & $\{\underline{\text { All Tariff, }}$ Total Subsidy $\}$ & 0.062 & 0.161 \\
\hline & $\mathrm{z} / \mathrm{e}$ & $z^{\mathrm{X}} / e^{\mathrm{X}}$ if in set of imports; $z^{\mathrm{X}} / e^{\mathrm{X}}$ if in set of exports & 4.278 & 5.015 \\
\hline & $\mathrm{z} / \mathrm{e} \times \mathrm{I} 10$ & & 4.059 & 5.090 \\
\hline & $\mathrm{z} / \mathrm{e} \times \mathrm{I} 25$ & & 3.630 & 5.154 \\
\hline & $\mathrm{z} / \mathrm{e} \times \mathrm{I} 33$ & & 3.630 & 5.154 \\
\hline & $\mathrm{z} / \mathrm{e} \times \mathrm{I} 40$ & & 3.079 & 4.843 \\
\hline & $\mathrm{z} / \mathrm{e} \times \mathrm{I} 50$ & & 2.785 & 4.810 \\
\hline & $\mathrm{z} / \mathrm{e}^{\times \mathrm{I} 60}$ & & 2.456 & 4.721 \\
\hline & $\mathrm{z} / \mathrm{e} \times \mathrm{I} 80$ & & 1.751 & 4.534 \\
\hline & $\mathrm{z} / \mathrm{e} \times \mathrm{I} 90$ & & 1.024 & 3.872 \\
\hline & PaymentConcentration & Geographic concentration measure based on govt. payments ( $\$ \mathrm{mn})$. & 295 & 659 \\
\hline & Farmland & Farmland (billion acres) & 0.108 & 0.119 \\
\hline
\end{tabular}

Notes: $\quad$ 1. M sample has $N=41$, X sample has $N=53$, and combined sample has $N=94$.

2. $I n=1$ if total PAC spending during $1993-98$ is greater than the $n$th percentile of the combined sample.

3. Export supply elasticities unavailable. Set equal to 2. 
Table 2: 2SLS estimates of coefficient $\beta_{1}$ [Equation (4)]

\begin{tabular}{|c|c|c|c|c|c|c|c|c|c|c|c|c|c|c|c|c|}
\hline \multirow[b]{3}{*}{ Dependent variable } & \multicolumn{14}{|c|}{ Regressor: } & \multirow{2}{*}{\multicolumn{2}{|c|}{$\begin{array}{l}\text { Range of } a \\
\text { estimates: }\end{array}$}} \\
\hline & \multicolumn{2}{|c|}{$\mathrm{z} / \mathrm{e} \times \mathrm{I} 10$} & \multicolumn{2}{|c|}{$\mathrm{z} / \mathrm{e} \times \mathrm{I} 25$} & \multicolumn{2}{|c|}{$\mathrm{z} / \mathrm{e} \times \mathrm{I} 33$} & \multicolumn{2}{|c|}{$\mathrm{z} / \mathrm{e} \times \mathrm{I} 40$} & \multicolumn{2}{|c|}{$\mathrm{z} / \mathrm{e} \times \mathrm{I} 50$} & \multicolumn{2}{|c|}{$\mathrm{z} / \mathrm{e} \times \mathrm{I} 60$} & \multicolumn{2}{|c|}{$\mathrm{z} / \mathrm{e} \times \mathrm{I} 80$} & & \\
\hline & coef & $t$ & coef & $t$ & coef & $t$ & coef & $t$ & coef & $t$ & coef & $t$ & coef & $t$ & Min & Max \\
\hline$\{$ Core NTM, Export subsidy\} & 0.016 & 4.91 & 0.016 & 4.80 & 0.016 & 4.80 & 0.017 & 4.75 & 0.018 & 4.66 & 0.018 & 4.34 & 0.021 & 3.77 & 47.6 & 62.5 \\
\hline$\{$ Core NTM, Total subsidy\} & 0.016 & 4.93 & 0.016 & 4.82 & 0.016 & 4.82 & 0.017 & 4.77 & 0.018 & 4.67 & 0.018 & 4.37 & 0.021 & 3.79 & 47.6 & 62.5 \\
\hline$\{$ Overall Protection, Export subsidy & 0.018 & 5.34 & 0.018 & 5.05 & 0.018 & 5.05 & 0.020 & 4.97 & 0.020 & 4.84 & 0.020 & 4.50 & 0.024 & 3.94 & 41.7 & 55.6 \\
\hline$\{$ Overall Protection, Total subsidy\} & 0.018 & 5.35 & 0.019 & 5.06 & 0.019 & 5.06 & 0.020 & 4.99 & 0.020 & 4.86 & 0.020 & 4.52 & 0.024 & 3.96 & 41.7 & 55.6 \\
\hline$\{$ All Tariff, Export subsidy\} & 0.011 & 2.93 & 0.010 & 2.58 & 0.010 & 2.58 & 0.011 & 2.51 & 0.011 & 2.39 & 0.011 & 2.30 & 0.012 & 1.97 & 83.3 & 100.0 \\
\hline$\{$ All Tariff, Total subsidy $\}$ & 0.011 & 2.96 & 0.010 & 2.60 & 0.010 & 2.60 & 0.011 & 2.55 & 0.011 & 2.43 & 0.011 & 2.34 & 0.012 & 2.00 & 83.3 & 100.0 \\
\hline
\end{tabular}

\section{Notes:}

1. $N=94$ in all models.

2. Dependent variable: $\{\mathrm{Y} 1, \mathrm{Y} 2\}$ implies the dependent variable is measured as $\mathrm{Y} 1$ is the observation is an import good, and $\mathrm{Y} 2$ if it is an export good. See Table 1.

3. z/e defined as (production/imports)/import demand elasticity| for imports set, and (production/exports)/export supply elasticity for exports set.

3. Shaded $t$-value cells denote statistical significance for right-tailed test: green at $1 \%$, tan at $5 \%$ and yellow at $10 \%$.

4. Five instruments used in the first stage: PaymentConcentration, Farmland, their squares and cross-product.

5. The $a$ estimates obtained by inverting the coefficient estimates -- see eq.(4).

6. The Sargan overidentification test cannot be rejected at the $5 \%$ level in any model. That is, the instruments pass the exogeneity test.

Table 3: Limited Information Maximum Information (LIML) estimates of coefficient $\beta_{1}$ [Equation (4)]

\begin{tabular}{|c|c|c|c|c|c|c|c|c|c|c|c|c|c|c|c|c|}
\hline \multirow[b]{3}{*}{ Dependent variable } & \multicolumn{14}{|c|}{ Regressor: } & \multirow{2}{*}{\multicolumn{2}{|c|}{$\begin{array}{l}\text { Range of } a \\
\text { estimates: }\end{array}$}} \\
\hline & \multicolumn{2}{|c|}{$\mathrm{z} / \mathrm{e} \times \mathrm{I} 10$} & \multicolumn{2}{|c|}{$\mathrm{z} / \mathrm{e} \times \mathrm{I} 25$} & \multicolumn{2}{|c|}{$\mathrm{z} / \mathrm{e} \times \mathrm{I} 33$} & \multicolumn{2}{|c|}{$\mathrm{z} / \mathrm{e} \times \mathrm{I} 40$} & \multicolumn{2}{|c|}{$\mathrm{z} / \mathrm{e} \times \mathrm{I} 50$} & \multicolumn{2}{|c|}{$\mathrm{z} / \mathrm{e} \times \mathrm{I} 60$} & \multicolumn{2}{|c|}{$\mathrm{z} / \mathrm{e} \times \mathrm{I} 80$} & & \\
\hline & coef & $t$ & coef & $t$ & coef & $t$ & coef & $t$ & coef & $t$ & coef & $t$ & coef & $t$ & Min & Max \\
\hline \{Core NTM, Export subsidy\} & $\overline{0.016}$ & 4.91 & 0.016 & 4.81 & 0.016 & 4.81 & 0.017 & $\overline{4.76}$ & 0.018 & 4.67 & 0.018 & 4.38 & $\overline{0.024}$ & 3.84 & 41.7 & 62.5 \\
\hline$\{$ Core NTM, Total subsidy\} & 0.016 & 4.93 & 0.016 & 4.82 & 0.016 & 4.82 & 0.018 & 4.78 & 0.018 & 4.69 & 0.019 & 4.41 & 0.024 & 3.86 & 41.7 & 62.5 \\
\hline$\{$ All NTM+Tar, Export subsidy $\}$ & 0.018 & $\overline{5.34}$ & 0.019 & 5.07 & 0.019 & 5.07 & 0.020 & 4.99 & 0.021 & 4.86 & 0.021 & 4.55 & 0.028 & 4.00 & 35.7 & 55.6 \\
\hline$\{$ All NTM+Tar, Total subsidy $\}$ & 0.019 & 5.36 & 0.019 & 5.08 & 0.019 & 5.08 & 0.021 & 5.01 & 0.021 & 4.88 & 0.022 & 4.57 & 0.029 & 4.02 & 34.5 & 52.6 \\
\hline$\{$ All Tariff, Export subsidy\} & 0.011 & 2.96 & 0.011 & 2.68 & 0.011 & 2.68 & 0.012 & 2.62 & 0.012 & 2.51 & 0.012 & 2.41 & 0.015 & $\overline{2.14}$ & 66.7 & 90.9 \\
\hline$\{$ All Tariff, Total subsidy\} & 0.011 & $3 \mathbf{3 . 0 0}$ & 0.011 & 2.72 & 0.011 & 2.72 & 0.012 & 2.66 & 0.012 & 2.55 & 0.012 & 2.46 & 0.015 & 2.18 & 66.7 & 90.9 \\
\hline
\end{tabular}
Notes:

1. See Notes $1-5$ in Table 2

2. The Anderson-Rubin overidentification test cannot be rejected at the $5 \%$ level in any model. That is, the instruments pass the exogeneity test. 
Table 4: LIML estimates $\beta 1$ [Equation (4)]: Political Organization based on predicted PAC spending

\begin{tabular}{|c|c|c|c|c|c|c|c|c|c|c|}
\hline \multirow[b]{3}{*}{ Dependent variable } & \multicolumn{8}{|c|}{ Regressor: } & \multirow{2}{*}{\multicolumn{2}{|c|}{$\begin{array}{l}\text { Range of } a \\
\text { estimates: }\end{array}$}} \\
\hline & \multirow{2}{*}{\multicolumn{2}{|c|}{$\begin{array}{l}\mathrm{z} / \mathrm{e} \\
\text { oef }\end{array}$}} & \multirow{2}{*}{\multicolumn{2}{|c|}{$\begin{array}{l}\mathrm{z} / \mathrm{e} \times \mathrm{I} 25 \\
\text { coef } t\end{array}$}} & \multicolumn{2}{|c|}{$\mathrm{z} / \mathrm{e} \times \mathrm{I} 50$} & \multicolumn{2}{|c|}{$\mathrm{z} / \mathrm{e} \times \mathrm{I} 75$} & & \\
\hline & & & & & coef & $t$ & coef & & Mir & Max \\
\hline \{Core NTM, Export subsidy\} & 0.013 & 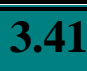 & 0.013 & 3.37 & 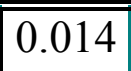 & 3.31 & $\overline{0.015}$ & 2.88 & 66.7 & $\overline{76.9}$ \\
\hline \{Core NTM, Total & 0.014 & 3.39 & 0.014 & 3.35 & 0.015 & 3.25 & 0.015 & 2.73 & 66.7 & 71.4 \\
\hline$\{$ All NTM+Tar, Ex & 0.015 & 3.67 & 0.015 & 3.62 & 0.016 & 3.51 & 0.017 & 3.02 & 58.8 & 66.7 \\
\hline$\{$ All NTM+Tar, Total subsidy $\}$ & 0.016 & 3.72 & 0.016 & 3.67 & 0.017 & 3.55 & 0.018 & 3.06 & 55.6 & 62.5 \\
\hline$\{$ All Tariff, Export subsidy\} & 0.012 & 2.46 & 0.012 & 2.44 & 0.012 & 2.33 & 0.013 & 2.07 & $76 . \subseteq$ & 83.3 \\
\hline$\{$ All Tariff, Total subsidy $\}$ & 0.012 & 2.52 & 0.012 & 2.50 & 0.013 & 2.38 & 0.013 & 2.13 & 76.5 & 83.3 \\
\hline
\end{tabular}

Notes:

1. $\mathrm{N}=94$ in all models (see appendix Table A1.

2. The first two columns report estimates from models with all sectors organized.

3. See Notes $1-5$ in Table 2.

Table 5: Limited Information Maximum Information (LIML) estimates of coefficient $\beta_{2}$ [Equation (5)]

\begin{tabular}{|c|c|c|c|c|c|c|c|c|c|}
\hline \multirow{3}{*}{$\begin{array}{c}\text { Dependent } \\
\text { Variable }\end{array}$} & \multicolumn{7}{|c|}{ Regressor: } & \multirow{2}{*}{\multicolumn{2}{|c|}{$\begin{array}{c}\text { Range of } a \\
\text { estimates }\end{array}$}} \\
\hline & $z^{\mathrm{M}} / e^{\mathrm{M}} \times I 10$ & $z^{\mathrm{M}} / e^{\mathrm{M}} \times I 25$ & $z^{\mathrm{M}} / e^{\mathrm{M}} \times I 33$ & $z^{\mathrm{M}} / e^{\mathrm{M}_{x I}} 40$ & $z^{\mathrm{M}} / e^{\mathrm{M}} \times I 50$ & $z^{\mathrm{M}} / e^{\mathrm{M}} \times I 60$ & $z^{\mathrm{M}} / e^{\mathrm{M}} \times I 80$ & & \\
\hline & coef $t$ & coef $t$ & coef $t$ & coef $t$ & coef $t$ & coef $t$ & coef $t$ & Min & Max \\
\hline Core NTM & 0.023 & $\begin{array}{l}0.024 \\
\end{array}$ & 年 $0.024 \quad 4.01$ & $\begin{array}{l}0.024 \quad 3.84 \\
\end{array}$ & 年 $0.025 \quad 3.72$ & $\begin{array}{l}0.0263 .50 \\
\end{array}$ & 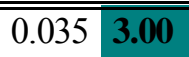 & 28.6 & (43.5 \\
\hline Over & 0.031 & $0.031 \quad 4.31$ & 0.0314 .31 & 0.032 & $0.033 \quad 3.94$ & $0.035 \quad 3.69$ & $0.048 \quad 3.08$ & 20.8 & 32.3 \\
\hline All Tariff & $0.016 \quad 2.44$ & $0.016 \quad 2.26$ & $0.016 \quad 2.26$ & $0.016 \quad 2.20$ & $0.016 \quad 2.11$ & $0.016 \quad 2.04$ & $0.021 \quad 1.92$ & 47.6 & 62.5 \\
\hline
\end{tabular}

Notes:

1. $\mathrm{N}=41$ in all models.

2. See Notes 2-5 in Table 2.

3. The Anderson-Rubin overidentification test cannot be rejected at the $5 \%$ level in any model. That is, the instruments pass the exogeneity test.

Table 6: Limited Information Maximum Information (LIML) estimates of coefficient $\beta_{3}$ [Equation (6)]

\begin{tabular}{|c|c|c|c|c|c|c|c|c|c|c|c|c|c|c|c|c|}
\hline & \multicolumn{14}{|c|}{ Regressor: } & \multirow{2}{*}{\multicolumn{2}{|c|}{$\begin{array}{l}\text { Range of } a \\
\text { estimates: }\end{array}$}} \\
\hline \multirow{2}{*}{$\begin{array}{l}\text { Dependent } \\
\text { Variable } \\
\end{array}$} & $\mathrm{z}^{\mathrm{X}} / e^{\mathrm{X}}$ & I10 & $z^{\mathrm{X}} / e^{\mathrm{X}} x$ & $\mathrm{I} 25$ & $z^{\mathrm{X}} / e^{\mathrm{X}}$ & I33 & $\mathrm{z}^{\mathrm{X}} / e^{\mathrm{X}}$ & $\times \mathrm{I} 40$ & $z^{\mathrm{X}} / e^{\mathrm{x}}$, & $\times \mathrm{I} 50$ & $z^{\mathrm{X}} / e^{\mathrm{X}} \times$ & $\times \mathrm{I} 60$ & $z^{\mathrm{X}} / e^{\mathrm{X}}$, & $\times \mathrm{I} 80$ & & \\
\hline & coef & $t$ & coef & $t$ & coef & $t$ & coef & $t$ & coef & $t$ & coef & $t$ & coef & $t$ & Min & Max \\
\hline $\mathrm{XS}$ & 0.004 & 1.48 & 0.004 & 1.41 & 0.004 & 1.41 & 0.008 & 2.03 & 0.01 & 2.17 & 0.013 & 2.58 & 0.043 & 2.11 & 23.3 & 250.0 \\
\hline TS & 0.005 & 1.52 & 0.005 & 1.44 & 0.005 & 1.44 & 0.009 & 2.05 & 0.011 & 2.20 & 0.014 & 2.60 & 0.046 & 2.13 & 21.7 & 200.0 \\
\hline
\end{tabular}

\section{Notes:}

1. $\mathrm{N}=41$ in all models.

2. See Notes 2-5 in Table 2.

3. The Anderson-Rubin overidentification test cannot be rejected at the 5\% level in any model. 
Table A1: First Stage regressions (Combined $\mathrm{M}$ and $\mathrm{X}$ sample)

\begin{tabular}{|c|c|c|c|c|c|c|c|}
\hline \multirow[b]{2}{*}{ Instruments } & \multicolumn{7}{|c|}{ Dependent Variable (endogenous variable in the structural model): } \\
\hline & $\mathrm{z} / \mathrm{e} \times \mathrm{I} 10$ & $\mathrm{z} / \mathrm{e} \times \mathrm{I} 25$ & $\mathrm{z} / \mathrm{e} \times \mathrm{I} 33$ & $\mathrm{z} / \mathrm{e} \times \mathrm{I} 40$ & $\mathrm{z} / \mathrm{e} \times \mathrm{I} 50$ & $\mathrm{z} / \mathrm{e} \times \mathrm{I} 60$ & $\mathrm{z} / \mathrm{e} \times \mathrm{I} 80$ \\
\hline PaymentConcentration & $\begin{array}{l}3.548 \\
(1.41)\end{array}$ & $\begin{array}{l}3.849 \\
(1.57)\end{array}$ & $\begin{array}{l}3.849 \\
(1.57)\end{array}$ & $\begin{array}{c}5.373 \\
(2.38)^{* *}\end{array}$ & $\begin{array}{c}5.471 \\
(2.47)^{* *}\end{array}$ & $\begin{array}{c}6.394 \\
(3.00)^{* * *}\end{array}$ & $\begin{array}{l}3.005 \\
(1.36)\end{array}$ \\
\hline Farmland & $\begin{array}{c}-48.31 \\
(2.20)^{* *}\end{array}$ & $\begin{array}{c}-56.13 \\
(2.63)^{* *}\end{array}$ & $\begin{array}{c}-56.13 \\
(2.63) * *\end{array}$ & $\begin{array}{c}-53.52 \\
(2.73)^{* * *}\end{array}$ & $\begin{array}{c}-62.65 \\
(3.26)^{* * *}\end{array}$ & $\begin{array}{c}-61.12 \\
(3.30)^{* * *}\end{array}$ & $\begin{array}{r}-17.20 \\
(0.90)\end{array}$ \\
\hline PaymentConcentration squared & $\begin{array}{l}0.531 \\
(0.66)\end{array}$ & $\begin{array}{l}0.477 \\
(0.61)\end{array}$ & $\begin{array}{l}0.477 \\
(0.61)\end{array}$ & $\begin{array}{l}0.156 \\
(0.22)\end{array}$ & $\begin{array}{l}0.232 \\
(0.33)\end{array}$ & $\begin{array}{l}0.037 \\
(0.05)\end{array}$ & $\begin{array}{l}0.871 \\
(1.24)\end{array}$ \\
\hline Farmland squared & $\begin{array}{c}155.38 \\
(1.80)^{*}\end{array}$ & $\begin{array}{c}171.37 \\
(2.03)^{* *}\end{array}$ & $\begin{array}{c}171.37 \\
(2.03)^{* *}\end{array}$ & $\begin{array}{c}179.96 \\
(2.32)^{* *}\end{array}$ & $\begin{array}{c}220.04 \\
(2.90)^{* * *}\end{array}$ & $\begin{array}{c}225.35 \\
(3.08)^{* * *}\end{array}$ & $\begin{array}{l}63.28 \\
(0.84)\end{array}$ \\
\hline PaymentConcentration* Farmland & $\begin{array}{c}-16.03 \\
(2.00)^{* *}\end{array}$ & $\begin{array}{l}-15.47 \\
(1.98)^{*}\end{array}$ & $\begin{array}{l}-15.47 \\
(1.98)^{*}\end{array}$ & $\begin{array}{c}-18.97 \\
(2.64)^{* * *}\end{array}$ & $\begin{array}{c}-22.83 \\
(3.25)^{* * *}\end{array}$ & $\begin{array}{c}-24.95 \\
(3.68) * * *\end{array}$ & $\begin{array}{c}-18.24 \\
(2.60)^{* *}\end{array}$ \\
\hline constant & $\begin{array}{c}4.754 \\
(6.47) * * * \\
\end{array}$ & $\begin{array}{c}4.668 \\
(6.52)^{* * *} \\
\end{array}$ & $\begin{array}{c}4.668 \\
(6.52)^{* * *}\end{array}$ & $\begin{array}{c}3.505 \\
(5.33)^{* * *} \\
\end{array}$ & $\begin{array}{c}3.291 \\
(5.11)^{* * *} \\
\end{array}$ & $\begin{array}{c}2.594 \\
(4.18)^{* * *}\end{array}$ & $\begin{array}{c}1.559 \\
(2.43)^{* *}\end{array}$ \\
\hline $\bar{N}$ & 94 & 94 & 94 & 94 & 94 & 94 & 94 \\
\hline$R^{2}$ & 0.24 & 0.29 & 0.29 & 0.32 & 0.34 & 0.37 & 0.27 \\
\hline First Stage $F$ & 5.47 & 7.28 & 7.28 & 8.47 & 9.19 & 10.19 & 6.35 \\
\hline
\end{tabular}

Table A2: First Stage regressions (Sample of Imported goods)

\begin{tabular}{l|ccccccc}
\cline { 2 - 8 } Instruments & \multicolumn{5}{c}{ Dependent Variable (endogenous variable in the structural model): } \\
\cline { 2 - 8 } & $z^{\mathrm{M}} / e^{\mathrm{M}} \times I 10$ & $z^{\mathrm{M}} / e^{\mathrm{M}} \times I 25$ & $z^{\mathrm{M}} / e^{\mathrm{M}} \times I 33$ & $z^{\mathrm{M}} / e^{\mathrm{M}} \times I 40$ & $z^{\mathrm{M}} / e^{\mathrm{M}} \times I 50$ & $z^{\mathrm{M}} / e^{\mathrm{M}} \times I 60$ & $z^{\mathrm{M}} / e^{\mathrm{M}} \times I 80$ \\
\hline \hline PaymentConcentration & 8.012 & 9.154 & 9.154 & 9.792 & 10.05 & 10.623 & 5.79 \\
& $(1.88)^{*}$ & $(2.18)^{* *}$ & $(2.18)^{* *}$ & $(2.32)^{* *}$ & $(2.35)^{* *}$ & $(2.48)^{* *}$ & $(1.27)$ \\
Farmland & 10.08 & -34.54 & -34.54 & -28.84 & -84.54 & -79.29 & 13.36 \\
& $(0.12)$ & $(0.43)$ & $(0.43)$ & $(0.36)$ & $(1.04)$ & $(0.97)$ & $(0.15)$ \\
PaymentConcentration squared & -0.863 & -1.033 & -1.033 & -1.169 & -1.047 & -1.169 & -0.014 \\
& $(0.72)$ & $(0.87)$ & $(0.87)$ & $(0.98)$ & $(0.87)$ & $(0.97)$ & $(0.01)$ \\
Farmland squared & -70.86 & 98.87 & 98.87 & 85.97 & 305.33 & 293.34 & -60.53 \\
& $(0.22)$ & $(0.31)$ & $(0.31)$ & $(0.27)$ & $(0.95)$ & $(0.91)$ & $(0.18)$ \\
PaymentConcentration* Farmland & -0.532 & -13.59 & -13.59 & -13.89 & -31.95 & -32.21 & -11.13 \\
& $(0.02)$ & $(0.50)$ & $(0.50)$ & $(0.51)$ & $(1.15)$ & $(1.16)$ & $(0.38)$ \\
constant & 4.003 & 4.215 & 4.215 & 3.57 & 4.22 & 3.633 & 1.884 \\
& $(2.46)^{* *}$ & $(2.63)^{* *}$ & $(2.63)^{* *}$ & $(2.22)^{* *}$ & $(2.58)^{* *}$ & $(2.22)^{* *}$ & $(1.09)$ \\
\hline$N$ & 41 & 41 & 41 & 41 & 41 & 41 & 41 \\
$R^{2}$ & 0.37 & 0.40 & 0.40 & 0.41 & 0.40 & 0.41 & 0.31 \\
First Stage $\boldsymbol{F}$ & $\mathbf{4 . 1 5}$ & $\mathbf{4 . 7 2}$ & $\mathbf{4 . 7 2}$ & $\mathbf{4 . 8 3}$ & $\mathbf{4 . 6 9}$ & $\mathbf{4 . 8 0}$ & $\mathbf{3 . 1 3}$ \\
\hline \hline
\end{tabular}

Notes:

1. Absolute $t$-values in parentheses: *** denotes statistical significance at $1 \%,{ }^{* *}$ at $5 \%$ and $*$ at $10 \%$.

2. See Table 1 for variable descriptions. 
Table A3: First Stage regressions (Export sample)

\begin{tabular}{|c|c|c|c|c|c|c|c|}
\hline \multirow[b]{2}{*}{ Instruments } & \multicolumn{7}{|c|}{ Dependent Variable (endogenous variable in the structural model): } \\
\hline & $z^{\mathrm{X}} / e^{\mathrm{X}} \times \mathrm{I} 10$ & $z^{\mathrm{x}} / e^{\mathrm{x}} \times \mathrm{I} 25$ & $z^{\mathrm{X}} / e^{\mathrm{X}} \times \mathrm{I} 33$ & $z^{\mathrm{x}} / e^{\mathrm{X}} \times \mathrm{I} 40$ & $z^{\mathrm{X}} / e^{\mathrm{X}} \times \mathrm{I} 50$ & $z^{\mathrm{x}} / e^{\mathrm{X}} \times \mathrm{I} 60$ & $z^{\mathrm{X}} / e^{\mathrm{X}} \times \mathrm{I} 80$ \\
\hline \multirow[t]{2}{*}{ PaymentConcentration } & $2-2.333$ & -2.53 & -2.53 & 0.004 & 0.007 & 1.354 & 1.11 \\
\hline & $(0.60)$ & $(0.68)$ & $(0.68)$ & 0.00 & 0.00 & $(0.75)$ & $(0.63)$ \\
\hline \multirow[t]{2}{*}{ Farmland } & -30.18 & -35.82 & -35.82 & -33.43 & -41.73 & -40.52 & -2.93 \\
\hline & $(1.32)$ & $(1.64)$ & $(1.64)$ & $(2.09)^{* *}$ & $(2.97)^{* * *}$ & $(3.83)^{* * *}$ & $(0.28)$ \\
\hline \multirow[t]{2}{*}{ PaymentConcentration squared } & 2.089 & 2.357 & 2.357 & 1.594 & 2.237 & 1.814 & -0.238 \\
\hline & $(0.67)$ & $(0.78)$ & $(0.78)$ & $(0.72)$ & (1.16) & $(1.25)$ & $(0.17)$ \\
\hline \multirow[t]{2}{*}{ Farmland squared } & 76.96 & 78.26 & 78.26 & 93.73 & 136.23 & 144.24 & 1.20 \\
\hline & $(0.84)$ & $(0.89)$ & $(0.89)$ & $(1.45)$ & $(2.40)^{* *}$ & $(3.38) * * *$ & $(0.03)$ \\
\hline \multirow[t]{2}{*}{ PaymentConcentration* Farmland } & -5.304 & -4.005 & -4.005 & -8.178 & -15.52 & -17.602 & -1.278 \\
\hline & $(0.33)$ & $(0.26)$ & $(0.26)$ & $(0.73)$ & $(1.57)$ & $(2.37)^{* *}$ & $(0.17)$ \\
\hline \multirow[t]{2}{*}{ constant } & 4.653 & 4.675 & 4.675 & 3.099 & 2.686 & 1.874 & 0.923 \\
\hline & $(5.95)^{* * *}$ & $(6.24)^{* * *}$ & $(6.24)^{* * *}$ & $(5.65)^{* * *}$ & $(5.58) * * *$ & $(5.17)^{* * *}$ & $(2.58)^{* *}$ \\
\hline $\bar{N}$ & 53 & 53 & 53 & 53 & 53 & 53 & 53 \\
\hline$R^{2}$ & 0.12 & 0.22 & 0.22 & 0.23 & 0.26 & 0.36 & 0.05 \\
\hline First Stage $F$ & 1.27 & 2.71 & 2.71 & 2.78 & 3.36 & 5.27 & 0.54 \\
\hline
\end{tabular}

Notes:

1. Absolute $t$-values in parentheses: ${ }^{* * *}$ denotes statistical significance at $1 \%,{ }^{* *}$ at $5 \%$ and $*$ at $10 \%$.

2. See Table 1 for variable descriptions. 